\title{
Landslide Hazard Assessment Using Probabilistic and Statistical Approaches: A Case Study of Chamba Region, Himachal Pradesh, India
}

Desh Deepak Pandey ( $\nabla$ deepak2171985@gmail.com )

National Institute of Technology Hamirpur https://orcid.org/0000-0002-1085-729X

Rajeswar Singh Banshtu

National Institute of Technology Hamirpur

Kanwarpreet Singh

Chandigarh University Mohali

Laxmi Devi Versain

National Institute of Technology Hamirpur

Research

Keywords: Middle Himalayan, National Highway, hazard, Mapping, Successive rate curve

Posted Date: September 8th, 2020

DOI: https://doi.org/10.21203/rs.3.rs-51845/v1

License: (a) (i) This work is licensed under a Creative Commons Attribution 4.0 International License.

Read Full License 


\title{
LANDSLIDE HAZARD ASSESSMENT USING PROBABILISTIC AND STATISTICAL APPROACHES: A CASE STUDY OF CHAMBA REGION, HIMACHAL PRADESH, INDIA \\ Pandey, D.D.*; Banshtu, R.S.**;Singh Kanwarpreet***; Versain, L.D. ****
}

deepak2171985@gmail.com*, Civil Engineering Department, National Institute of Technology, Hamirpur, H.P., India banshtu.rajeshwar@gmail.com**, Civil Engineering Department, National Institute of Technology, Hamirpur, H.P., India kanwarpreet.e9570@cumail.in***, Civil Engineering Department, Chandigarh University, Mohali, Punjab, India verasin.laxmi@gmail.com****, Civil Engineering Department, National Institute of Technology, Hamirpur, H.P., India

\begin{abstract}
Landslides have adversely affected the southern region of Chamba district during past three decades. To minimize the damage to ecology and environment due to such natural calamities, landslide hazard zonation and mitigation measures are essential component to stabilize the natural slopes and other physiographic features. In order to remodeling lopsidedness in study area analytical hierarchy process and information value methods with applications of remote sensing and geographic information system (GIS) are utilized to delineate the most recumbent landslide hazard zones. Eleven-factor maps like slope gradient, slope aspect, relative relief, land use/ cover etc., were delineated using different sets of data like satellite images and field investigations etc. Depending upon the severity, landslide hazard maps (LHZ) were further divided based upon information value method and analytical hierarchy process models respectively, into five different categories very low $(1.2 \%$ and $2.95 \%)$, low $(5.31 \%$ and $4.27 \%)$, moderate $(24.40 \%$ and $20.03 \%)$, high $(29.26 \%$ and $31.03 \%)$, and very high $(40.30 \%$ and $44.2 \%)$. These hazard maps obtained through both information value and analytical hierarchy process (AHP) were compared for accuracy using success rate curve (SRC) method. Accuracy of the hazard zonation maps was found to be $78.62 \%$ for AHP and $85.17 \%$ for Inf. Value models.
\end{abstract}

Keywords: Middle Himalayan, National Highway, hazard, Mapping, Successive rate curve.

\section{Introduction}

Landslide is a significant environmental risk, instigating destruction to life and infrastructure. Several authors categorize landslides such as: fall, topple and flow, spread, slide etc. in terms of rock, debris, and earth under the influence of the gravitational forces in the downward and outward direction of the slope (Varnes and IAEG, 1984; Crozier 1986; Couture 2011). The strength of the slope forming materials and slope angle controls the stability of the slope. Past landslide records, intensive field work and professional experience play important role in the selection of the essential factors. The Indian states of Jammu and Kashmir, Himachal Pradesh, Uttarakhand, and Sikkim often get disturbed due to landslides during every monsoon. Districts like Chamba, Kangra, Mandi, Kullu, Bilaspur, and Shimla are highly affected by landslides in the state of Himachal Pradesh. Hence, a vulnerable stretch from Lahru to Chamba along NH-154A via Banikhet was selected for LHZ assessment in the present study. Landslides associated with the river beds are affected due to the undercutting of the toe of slopes. The economy of Himachal Pradesh and Government of India is adversely affected by these slope failures and in some cases many lives were also lost. Mitigation and remedies for the slope failures in study area has been useful after identification of landslide hazard zones.

The mountainous terrain of district Chamba in Himachal Pradesh is suffering from landslide disaster mainly in the region where slope gradient is greater than $40^{\circ}$ which is harming lives and million dollars property across the region. An earthquake triggered landslides caused death of around 500 people in Chamba in year 1905. The inherent and extrinsic landslide causative factors like geomorphological, geological, hydrology, soil, landuse land cover (LULC), rainfall, seismic etc. play important role for causing landslide movement(Cruden and Varnes 1996; Courture 2011)from which the geology, soil, and LULC are the major factors contributing in landslides (Varnes 1984; Anbalagan 1992; Hutchinson1995; Achour et al.2017). The constructional activities of infrastructural mega projects are also disturbing hilly terrains in this region. Hence, the landslide hazard assessment is essential in the region for future development and construction.

A minimal work has been found on the landslide hazard assessment using GIS is present study area based on the qualitative (Probabilistic) and quantitative (Statistical) approaches. The qualitative methods like landslide hazard evaluation factor (LHEF) (BIS code 1998) and analytical hierarchy process (AHP) (Saaty 1980) were widely adopted in literature (Sudhakar and Pardeshi et. al. 2013) by geologists and geotechnical engineers during year 1970 to 1980 (Aleotti et. al 1999). The matrix formation form pairwise comparison through the desired weight values 
based on experts experience are essential components for qualitative analysis in AHP for LHZ assessment. The quantitative methods for LHZ assessment generally depends upon the percentage of the landslide and landslide controlling factors. Statistical (information value, frequency ratio, weight of evidence etc.) and deterministic methods (fuzzy logic, logistic regression, and artificial neural network etc.) are the example of quantitative methods (Ercanoglu and Gokceoglu, 2002; Suzen and Doyuran, 2004; Ercanoglu and Gokceoglu, 2004; Yesilnacar and Topal, 2005; Kanungo et al., 2006; García-Rodriguez et al., 2008; Nefeslioglu et al., 2008; Nandi and Shakoor, 2009; Dongyeob Kim et al., 2010; Pradhan B., 2012). Distribution of landslide events and landslide controlling parameters are correlated with historical events by using statistical methodology (Refice and Capolongo, 2002; Zhou et al., 2003). The influence of rainfall has also been analyzed in terms of thresholds for triggering landslides by various researchers (Iverson 2000; Crosta and Frattini 2003; Brooks et al. 2004; Montrasio et al. 2012; Salciarini et al.2012; Ran et al. 2012; Marchi et al. 2002; Floris et al.2004; Giannecchini2005; Kanungo and Sharma 2014; and Chung et al. 2016).

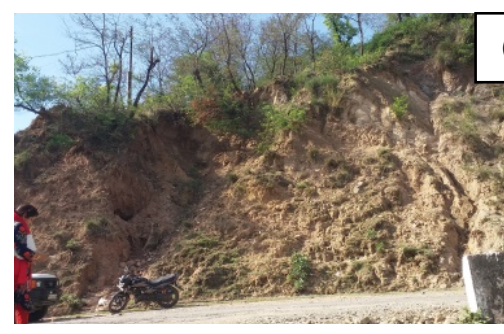

(a)

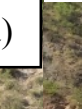

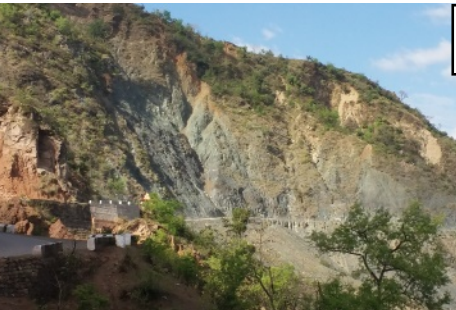

(b)

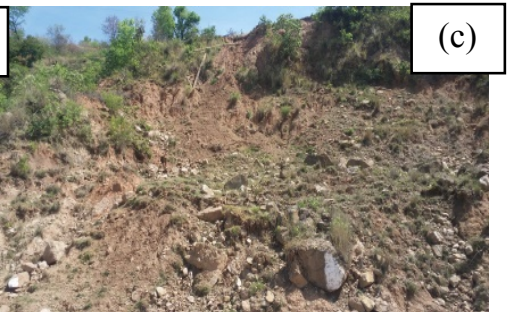

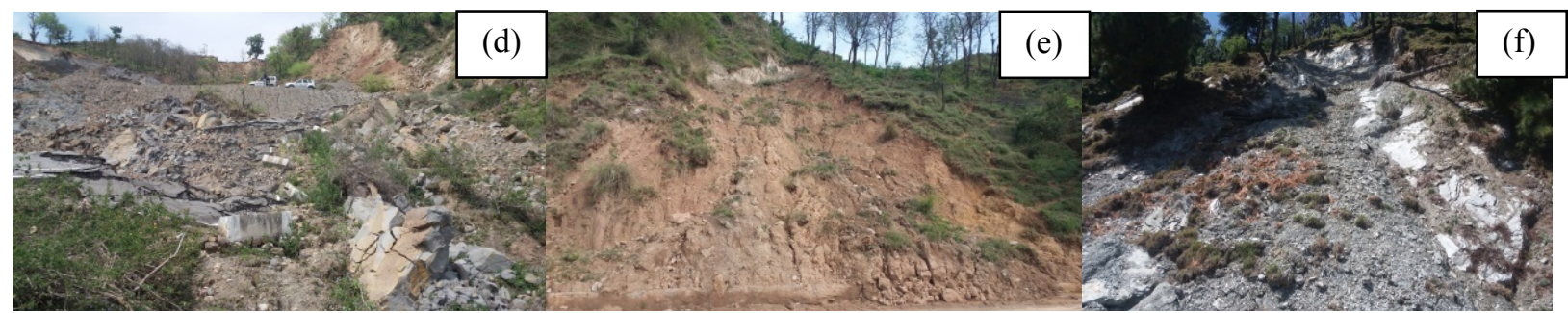

Figure 1: Photographs of critical slopes taken during March 2019 field visit along SH28 and NH -154A (a) Earth debris failure 500m from Lahru at SH28 (b) Transitional and Rock debris landslide near Chowari at SH28, (c) Debris flow landslide neat Jot at SH28 (d) Rock fall and Earth flow landslide $250 \mathrm{~m}$ before Ghatasani bridge at NH145-A (e) Earth Debris flow landslide near Banikhet at NH-154A (f) Rock fall landslide near Chamba at NH154A.

\section{Study area}

Study area covers $27355.47 \mathrm{~m}^{2}$ area enveloped between $80.84 \mathrm{Km} \mathrm{NH}-154 \mathrm{~A}$ from Lahru to Chamba via Banikhet $\left(76^{\circ} 10^{\prime} \mathrm{E}, 32^{\circ} 35^{\prime} \mathrm{N}\right)$ and $54.90 \mathrm{Km}$ along the state highway 28 from Lahru to Chamba via Jot $\left(75^{\circ} 51^{\prime} \mathrm{E}, 32^{\circ} 26^{\prime}\right.$ N). The area has a dendritic drainage pattern and can be easily identified on using Survey of India 1986 topographic sheets $(43 \mathrm{P} / 14,43 \mathrm{P} / 15,52 \mathrm{D} / 2$ and $52 \mathrm{D} / 3)$ on the scale of $1: 50,000$. The study area has high relief with altitude ranging from 656 feet near Lahru to 2757 feet in Dalhousie. Maximum temperature in summer is $30^{\circ} \mathrm{C}$ whereas minimum is $14^{\circ} \mathrm{C}$ while in winter season temperature varies between $2^{\circ} \mathrm{C}$ to $11^{\circ} \mathrm{C}$. Rainfall of $186.42 \mathrm{~mm}$ was recorded during the year 2018 in this region (Indian meteorological department).

86

87

88

89

90

91

92

93

94

95

96

97

98
Climate conditions and physiography are the root cause of slope failures in the study area. On $2^{\text {nd }}$ August 2018 one bus was washed out and road was blocked for the almost one day reported in several local newspapers and media. During the monsoon period of 2017 and 2018 landslide measuring 434m length and 136m wide has taken place below the Bindgi village, Bhattiyat tehsil near hair pin bend (7557'11.70"E, 32 $26^{\prime} 19.21^{\prime \prime} \mathrm{N}$ to $75^{\circ} 57^{\prime} 16.49^{\prime \prime} \mathrm{E}$, $32^{\circ} 26^{\prime} 20.11^{\prime \prime} \mathrm{N}$ and $75^{\circ} 57^{\prime} 12.99^{\prime \prime} \mathrm{E}, 32^{\circ} 26^{\prime} 17.81^{\prime \prime} \mathrm{N}$ to $\left.75^{\circ} 57^{\prime} 16.83^{\prime \prime} \mathrm{E}, 32^{\circ} 26^{\prime} 19.33^{\prime \prime} \mathrm{N}\right)$. Mountain slopes are affected by human interferences for development and unplanned construction although rainfall and seismic activities also play vital role for triggering landslides. Transitional landslide was found along NH-154A at a distance of about 250m Ghatasani Bridge damaging around $800 \mathrm{~m}$ road stretch as reported by Hindustan, Times of India and as per records of H.P Public Works Department. Debris flow caused damage to NH nearby 500m from Lahru at July 14, 2017 as reported by the Tribune and Times of India. Road construction initiated huge translational slide due to movement of thrust near Chowari has also been reported (Singh and Thakur 1989, Keshar Singh 2011). 

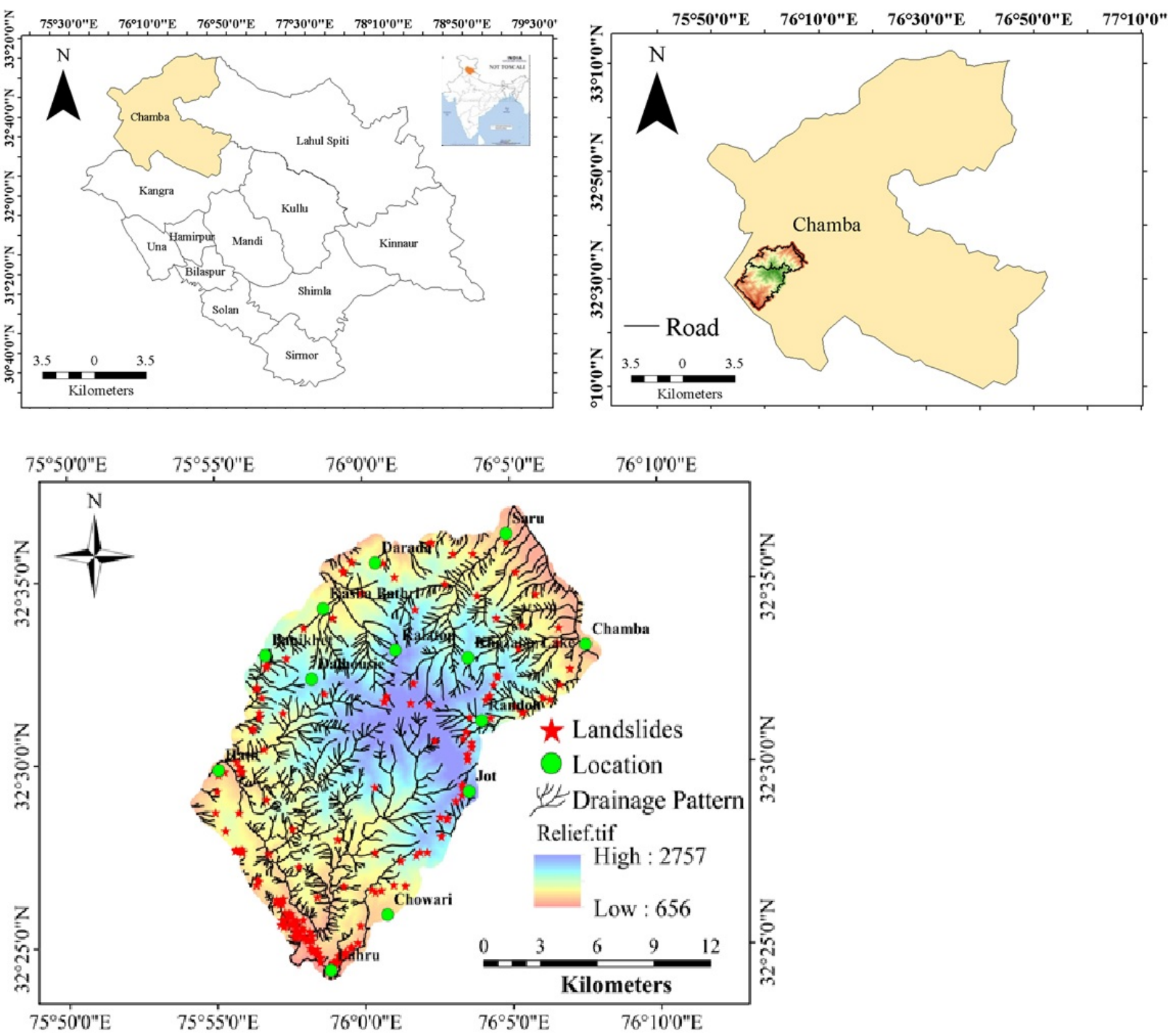

Figure 2: Study area Lahru to Chamba, Chamba District, and Himachal Pradesh, India

\section{Geological Setting}

Regional geological setup in study area consists of a large syncline called Chamba syncline, having metasedimentary rocks with $8-10 \mathrm{~km}$ thickness belonging to Cambrian to Triassic era. Subordinate phyllites with laminated cross-bedded quartzite are main subsistence of the Chamba formations. Phyllites, slates and limestones are foundation of the Shali formation which is overlain by the alluvium. PindruFormation rock bodies are subsistence with interstratified schist, quartzite, staurolite, schist and conglomerate. KhokanFormation rock bodies are surrounded by Vaikrita thrust. Kalhel rock bodies of Kalhel formation (Lilang Group) is found in pockets which were overlaid by GharFormation. Upper Siwaliks rock bodies are youngest formation of rocks in the region shown in Table 1.Tectonic activity of the region is the cause of frequent the seismic activities in the region. Seismic activity of 6.5 magnitude in year 1945 near Chamba town, massive landslides were occurred at various places i.e. Chamba, Jot, Chowari, Banikhet, and Darada etc. Earthquake of 6.2 magnitudes in 1947 played vital role in activation of slope failure $1 \mathrm{~km}$ short of Chowari. Subsequent earthquake varying 4 to 4.5 magnitude in 1950, 1955 and 2005 triggered some slope failures likely near Banikhet $500 \mathrm{~m}$ before Chamba District (Sharma et al. 2005). Amateur seismic center (Pune, Maharastra), based on the earthquakes records put Chamba region in Zone V. Lesser Himalayan lies in a wide zone which is located in between the "main boundary thrust (MBT) and main central thrust (MCT)" that runs along the base of the frontal range (Deeken et al., 2011). 
Table 1: Geological succession of study area (Ratan SS (1973), Thakur VC and Rawat BS (1992) and Geological wing, department of industries, government of Himachal Pradesh)

\begin{tabular}{|c|c|c|c|c|}
\hline Era & Origin & Formation & Group & Rock types \\
\hline Recent/Holocene & Sedimentary & \multicolumn{3}{|l|}{ Alluvium } \\
\hline \multicolumn{5}{|c|}{--------------------------------------------------Vaikrita Thrust (VT) ------------------------------------------------ } \\
\hline \multirow[t]{3}{*}{$\begin{array}{l}\text { Upper Pliocene to } \\
\text { lower Pleistocene }\end{array}$} & \multirow[t]{3}{*}{ Sedimentary } & \multirow[t]{3}{*}{ Siwalik } & $\begin{array}{l}\text { Upper } \\
\text { Siwalik }\end{array}$ & $\begin{array}{l}\text { Coarse sandstones, conglomerates, coarse } \\
\text { boulder, clays, sands and grits }\end{array}$ \\
\hline & & & $\begin{array}{l}\text { Middle } \\
\text { Siwalik }\end{array}$ & $\begin{array}{l}\text { Coarse micaceous Sandstones with } \\
\text { interbeds of earthy clay }\end{array}$ \\
\hline & & & $\begin{array}{l}\text { Lower } \\
\text { Siwalik }\end{array}$ & Sandstones - clay alternation \\
\hline Lower Miocene & Sedimentary & $\begin{array}{l}\text { Dharmsala } \\
\text { formation }\end{array}$ & --- & $\begin{array}{l}\text { Coarse micaceous Sandstones with inter } \\
\text { beds of earthy clay }\end{array}$ \\
\hline Middle Miocene & Sedimentary & $\begin{array}{l}\text { Khalel } \\
\text { formation }\end{array}$ & $\begin{array}{l}\text { Lilang } \\
\text { Group }\end{array}$ & Sandstones - clay alternation \\
\hline Lower Paleozoic & Igneous & $\begin{array}{l}\text { Dalhousie } \\
\text { Granite }\end{array}$ & --- & Micaceous Granite \\
\hline \multicolumn{5}{|c|}{ 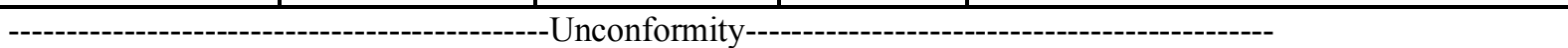 } \\
\hline Late Proterozoic & Sedimentary & $\begin{array}{l}\text { Manjir } \\
\text { formation }\end{array}$ & --- & $\begin{array}{l}\text { Grey and purple para-conglomerates with } \\
\text { some intercalated bands of grey slates. } \\
\text { Few quartzites bands in the lower part in } \\
\text { some sections. }\end{array}$ \\
\hline \multirow[t]{4}{*}{$\begin{array}{l}\text { Middle to upper } \\
\text { Proterozoic }\end{array}$} & Sedimentary & $\begin{array}{l}\text { Chamba } \\
\text { formation }\end{array}$ & --- & $\begin{array}{l}\text { Monotonous alternations of meta } \\
\text { greywacke and slate forming shalyflysch. }\end{array}$ \\
\hline & Metamorphic & $\begin{array}{l}\text { Pindru } \\
\text { formation }\end{array}$ & --- & $\begin{array}{l}\text { Greyish green, sometimes } \\
\text { talcosephyllites and } \\
\text { garnetiferousbiotite } \\
\text { micaceousquartzites and interbedded with } \\
\text { some bands of dark grey crystalline } \\
\text { limestone, with associated Dalhousie } \\
\text { granite. }\end{array}$ \\
\hline & Metamorphic & $\begin{array}{l}\text { Khokan } \\
\text { formation }\end{array}$ & --- & Chlorite Mica Schists, Slate and Quartzite \\
\hline & Metamorphic & $\begin{array}{l}\text { Ghar } \\
\text { Formation }\end{array}$ & $\overline{---}$ & Para-gneisses \\
\hline \multicolumn{5}{|c|}{-------------------------------------------Main Central Thrust (MCT)---------------------------------------------- } \\
\hline $\begin{array}{l}\text { Lower } \\
\text { Proterozoic }\end{array}$ & Igneous & $\begin{array}{l}\text { Mandi } \\
\text { formation }\end{array}$ & $\begin{array}{l}\text { Darla } \\
\text { volcanic } \\
\text { rocks }\end{array}$ & Basaltic and andesitic flows \\
\hline
\end{tabular}

\section{MATERIALS AND METHODOLOGY}

\section{Data Source}

Selection of the rightful elements with their assistance in the landslide occurrences is necessary (Ayalew and Yamagishi 2005). Varnes 1984, representation of all factors responsible for slope failures must be required for hazard zonation of landslides. Stability of slopes was influenced by the surface topography than the geomorphology of the terrain (Dai and Lee 2002). The researchers (Varnes 1984; Kanungo et al. 2009) suggested that factors like: slope, aspect, curvature, relative relief, soil, Land use and land cover (LULC), lithology, geomorphology, rainfall, drainage density, and lineament density are the main contributors of the slope failures in Himalayan terrain. LULC and inventory of landslides were generated through the LISS IV satellite imagery and Google Earth images. Validation of the identified landslides and land cover was done through various field visits. Relative relief, slope

133 gradient, slope aspect, and curvature were generated through the 3D PAN Satellite imagery of CartoSat -1D with 
resolution of 30m. Subsidiary data like drainage was developed from Survey of India 1986 topographic sheets (1:50,000), lithological and lineament map from Keshar Singh and V. C. Thakur 1989, Keshar Singh 2011 and 1993. The rainfall record from January 2000 to February 2019 was collected from Indian meteorological center Shimla. Other maps were generated from data provided by the concerned governmental and non-governmental agencies (Table 2). Figure 3 shows all the landslide causative factor maps which were correlated with the mass movements

Table 2: Data Type/Source for LHZ Mapping

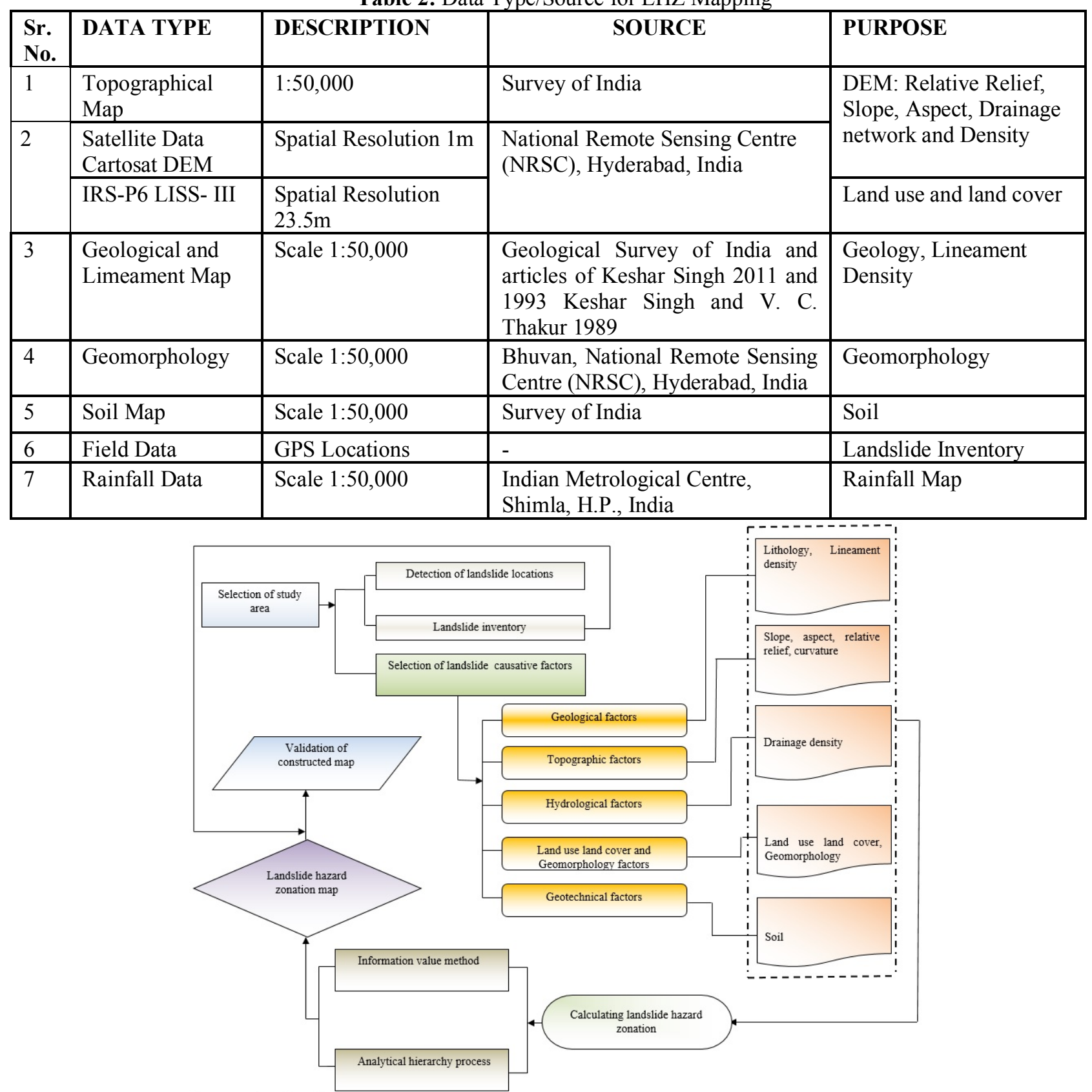

Figure 3: Flow chart for landslide hazard zonation mapping

(a) Analytical Hierarchy Process (AHP)

Analytical Hierarchy Process technique was utilized by various researchers for landslide hazard zonation. The AHP technique is useful in evaluation of different parameters role in slope failure (Varnes 1990 and 1980, Satty 2005, Feizizadeh and Blaschke 2012). It is based on three principles: decomposition, comparative judgment and synthesis of priorities (Pandey et al. 2016, Singh and Sarda2018). 
Weight of each class of landslide causative factor is analyzed using AHP approach through the comparison of each pair in the form of pairwise comparison matrix. Weights were assigned in the scale of 1-9 (equal importance 1, moderate importance 3 , strong importance 5, very strong importance 7 and extremely importance as 9) on the basis of importance of each factor in triggering the failure of the slopes. Results of inverse comparison are reciprocal (1/2 to 1/9) for the given weight to mandatory triggering element. Consistency of each matrix was validated through the consistency ratio (Satty 1990, 1994) which is analyzed for each factor from the weights of each element through equation 1 and 2 .

$$
\text { Consistency Ratio }(C R)=\frac{\text { Consistency } \operatorname{Index}(C I)}{\text { Random Index }(R I)}
$$

Consistency Index $(C I)=\frac{\lambda_{\max }-n}{n-1}$

Where, order of matrix as ' $n$ ' and ' $\lambda_{\max }$ ' denoted as matrix principle eigen value and Random index values were used from table 3 .

$$
L H I=\sum_{j=1}^{n} W_{k} \times W_{i k}
$$

Table 4: Random Index values for different matrix orders $(\mathrm{N})$

\begin{tabular}{|l|l|l|l|c|c|c|c|c|c|c|}
\hline $\mathbf{N}$ & $\mathbf{1}$ & $\mathbf{2}$ & $\mathbf{3}$ & $\mathbf{4}$ & $\mathbf{5}$ & $\mathbf{6}$ & $\mathbf{7}$ & $\mathbf{8}$ & $\mathbf{9}$ & $\mathbf{1 0}$ \\
\hline $\mathbf{R I}$ & 0 & 0 & 0.52 & 0.89 & 1.11 & 1.25 & 1.35 & 1.4 & 1.45 & 1.49 \\
\hline
\end{tabular}

Weight values assigned for the different factors on their importance in the form of matrix are shown in Table 3. Reciprocal weight values were given for inverse comparison of factors based on dominant causative factor. CR value less than 0.1 indicates reasonable consistency level of weight values (Satty and Vergas 2000). Finally to analyze landslide hazard index (LHI) values, all weights were combined by using equation 3 .

Where, $\mathrm{LHI}=$ landslide hazard index values; $\mathrm{W}_{\mathrm{ik}}=$ weight of subclass $i$ in factor $k$; $\mathrm{W}_{\mathrm{i}}=$ weight of the factor $k ; n$ $=$ total number of factors.

\section{(b) Information value model}

Based on assumption factors responsible for slope failures in past was the same that will cause landslides in future. Distributions of landslides based on their location, size and type were compared with each causative factor for assigning the weight values. Assignments of weight values were depend upon the density of landslides in each class of the factor (Lin and Tung 2003). Information value model (IVM), weight of evidence (WOE), frequency ratio (FR) and weighted overlay etc. statistical methods were used for the analysis of weights values. Van Westen 1993 modified the information value model proposed by Yin and Yan 1988. Researcher has used information value model for landslide hazard zonation mapping in such study. Rainfall, slope gradient, slope aspect, geology, drainage density, lineament density, geomorphology, relative relief, land use/cover soil and curvature factors plays very important role in failures of slopes. This method aims to find the probability of a landslide event based on the comprehensive information available of the significant factors by using equation 4 .

$$
l\left(L x_{i}\right)=\ln \frac{N p i x(S i) / N p i x(N i)}{\sum N p i x(S i) / \sum N p i x(N i)}
$$

Where, factor of class information value $l\left(\mathrm{Lx}_{\mathrm{i}}\right)$, number of landslide pixels in each class Npix $(\mathrm{Si})$, total number of pixels in each class $\operatorname{Npix}(\mathrm{Ni})$, sum of landslide pixels in the study area $\sum \operatorname{Npix}(\mathrm{Si})$, sum of total pixels in the study area $\sum \mathrm{Npix}(\mathrm{Ni})$. Equation 5 analyzes the landslide hazard index values through summing of all weight values.

$$
L H I=\sum_{i=1}^{n} l\left(L x_{i}\right)=\sum_{i=1}^{n} \frac{N p i x(S i) / N p i x(N i)}{\sum N p i x(S i) / \sum N p i x(N i)}
$$

Where LHI indicates the landslide hazard index values, $\mathrm{n}$ denotes the total number of factors. LSI $<0$ indicates the less than likelihood average, LSI $=0$ indicates the landslide likelihood equal to the average, LSI $>0$ indicates the average of landslides. 


\section{Thematic Layers}

Interpretation of satellite images, past landslide records from different agencies and field surveys play significant role in the development of landslide inventory (Kayastha et al. 2013). In the present study, inventory of 184 landslides was developed by collecting data from the past records of border road organization (BRO), public works department (PWD), National Highway Authority of India (NHAI) and LISS IV satellite images and Google earth images which were validated through field visits and updated to present day status (Figure 4a). The cause of maximum numbers of landslides (debris and rock falls) are correlated with thrusts and lineaments. Rock fall near Chowari town and $20 \mathrm{~km}$ before Chamba town weretriggered by the seismic shocks and rainfall (Fig $1 \mathrm{~b}$ and $\mathrm{f}$ ), debris flow at $500 \mathrm{~m}$ from Lahru town and Banikhet landslides took place due to heavy rainfall which is triggering factor for $75 \%$ of the total landslides in the area.

\section{(b) Lithology}

Lithology holds an important role in the stability of the mass movements, in minimizing the erosions and in weathering of rocks as well (Anabalgan 1992). Upper Shiwalik, Pindru, Mandi, Khokan, Khalel (Lilang group), Ghar, Dharmsala and Chamba formation, Dalhousie granite with alluvium rock bodies and their sequence of succession has been presented in Figure 4(b) and Table 2. Lithology map for the study was developed from the articles of Keshar Singh 2011 and 1993 Keshar Singh and V. C. Thakur 1989.

\section{(c) Land use and land cover}

Contribution of land use/ cover in slope failures has been reported well in literature by several researchers(Lee et al. 2013). Landslide prone areas are the evidences of land use changes like road expansions, new construction activities (homes, bridges and reservoirs), deforestation and rapid expansion in agriculture fields (Jaiswal et al. 2010). Comparison of past data (SOI topographic sheets(43P14, 43P15, 52D2 and 52D3)) with the present data (Google earth, LISS IV satellite imageries) has been employed in the preparation of LULC map through digitization and change detection tool as presented in Figure 4(c). Forest, sparse vegetation and agriculture classes of the region have been found to cover $79.63 \%$ while water bodies and snow occupied only $1.08 \%$ area.

\section{(d) Soil}

Five types of soils were found in the study area like loamy skeletal soil with loamy surface, rocky outcrops, coarse loamy, loamy and sandy skeletal soils (Figure 4d). Coarse loamy soil covered a minimum area of 3.49\% while $35.47 \%$ maximum area was found to be covered with loamy skeletal soil. Landslides were found to be more prone in sandy skeletal soil.

\section{(e) Drainage Density}

Drainage density plays an important role in the weathering and soil erosion on the slopes(Demir et al. 2013). Orientation of lineaments was followed by the stream networks in region. Density of stream networks depends upon the ground water conditions (Kavzoglu et al. 2014). Stream networks were extracted from satellite imagery of Cartosat -1D sensor by using hydrology tool of spatial analyst in ESRI (Arc GIS) software and digitization of survey of India topographic sheets at the scale of 1:50,000. Drainage density map was developed by using equation 6 and reclassified into four classes (Very low, low, moderate and high drainage density) Figure 4(e).

$$
\text { Drainage Density }=\frac{{ }^{\text {Total Stream Length }}}{\text { Total Drainage Area }}=\frac{\sum_{i}^{n} L}{\sum A}
$$



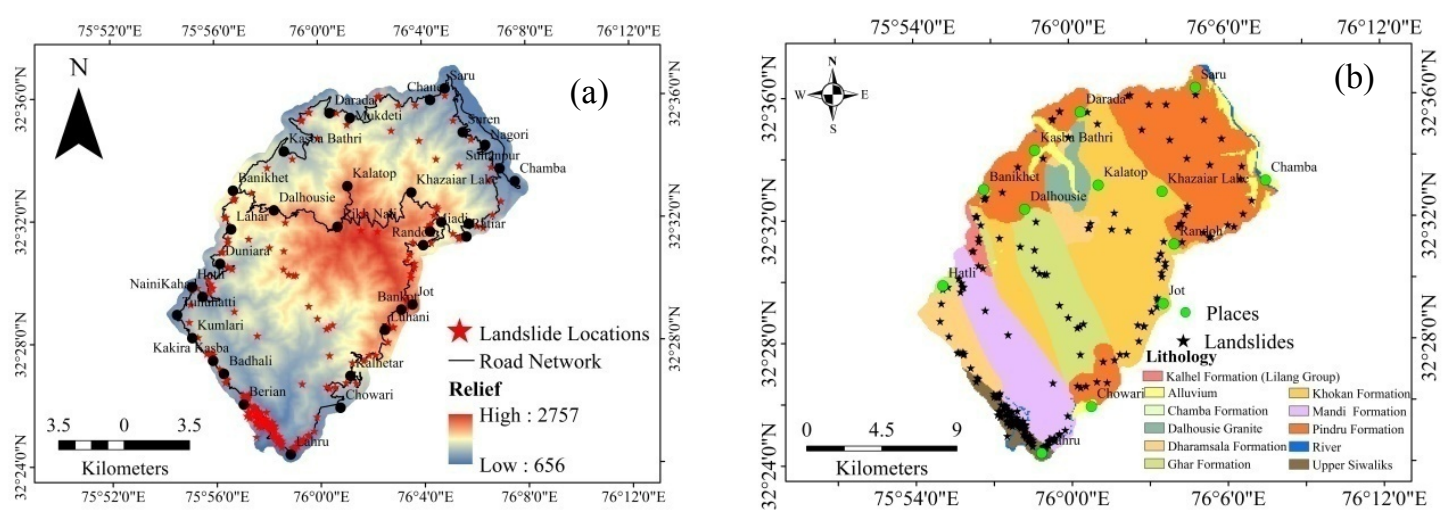

246
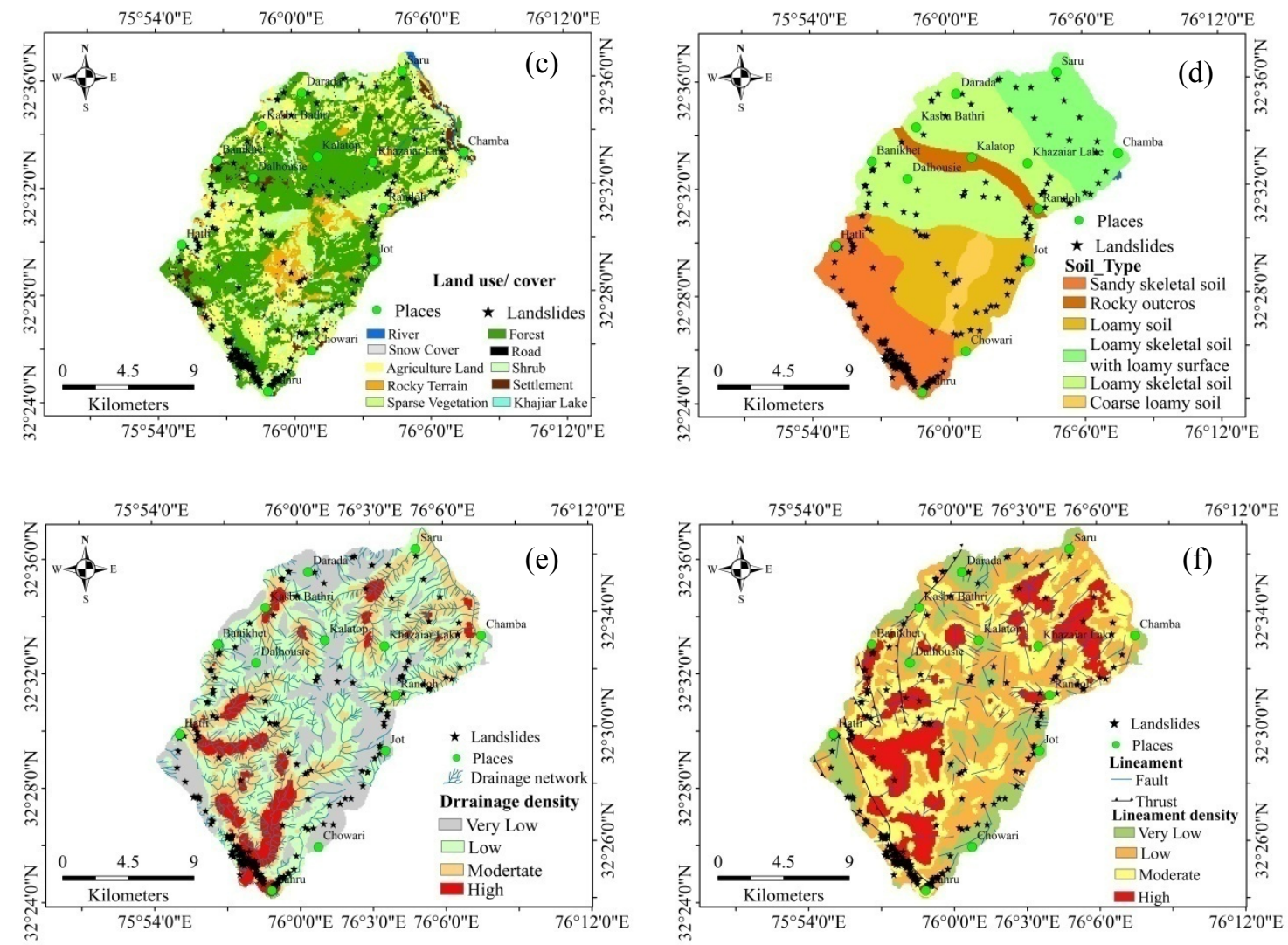

Figure 3:Thematic data layers (a) Landslide inventory map, (b)Lithology map, (c) Land use and cover map (d)

\section{(f) Lineament Density}

Role of rock cleavages, joints and fault planes are very important for controllingpore pressure (Ramakrishnan et al. 2013). Intense shearing of rocks is directly affected by the active fault planes which leads rock masses of mountains towards failures (Leir et al. 2004). Lineament density map was prepared from the various literatures and maps at the scale of 1:50,000, National remote sensing center (NRSC), Indian space research organization (ISRO). Lineament 259 density map has been classified into three classes viz. low, moderate and high density based on equation 7 (Figure $4 f)$.

Lineament Density $=\frac{\text { Total Lineament Length }}{\text { Total Lineament Area }} \stackrel{\frac{2 \sigma_{n}}{\sum}}{\sum A}$ 
Slope value is calculated on the basis of change in altitude. Slope degree plays vital role for controlling slope stability (Lee and Min 2001). Figure 4(g) shows the reclassification of slope map into five subclasses (Normal slope $0-15^{\circ}$, Low $15^{\circ}-30^{\circ}$, Moderate $30^{\circ}-45^{\circ}$, Steep $45^{\circ}-60^{\circ}$, Very steep $60^{\circ}-80^{\circ}$ ).

\section{(h) Geomorphology}

The geomorphology map of the study area was delineated at the scale of 1:50,000 based on the Landsat, Cartosat 1D and Google earth images. Structural, Denudational, low and moderate dissected hills were identified and validated through filed visits. River and flood plains of river covers only $4.56 \%$ of the area while $95.44 \%$ of area is covered by the structural and denudational hills as shown in Figure $4 \mathrm{~h}$.

\section{(i) Slope Aspect}

The aspect of a slope is known as direction of the slope facet with respect to north. Aspect of slopes depends upon the dryness of air, soil moisture and solar heat effect (Yalcin 2008). The slope aspect map was classified into eight classes viz. north, north east, east, south east, south, south west, west and north west as mentioned in Figure 4i.

\section{(j) Rainfall}

Rainfall is an important causative factor in the occurrences of slope failures. Rainfall data of different metrological stations in the region was collected and analyzed from January 2000 to February 2019. Lowest rainfall record is $1437 \mathrm{~mm}$ in year 2002 and maximum rainfall 1691mm in year 2017 was recorded in region. Kriging tool of GIS is used for development of rainfall map. Rainfall map of the study area was reclassified into four class'sviz. 1437$1547 \mathrm{~mm}, 1548-1627 \mathrm{~mm}, 1628-1691 \mathrm{~mm}$, and 1692-1752mm as shown in Figure 4(j).

\section{(k) Relative Relief}

Slopes angles and direction of slopes depend upon altitude rangeof the area. Altitude ofLahru town is $656 \mathrm{~m}$ and Kalatopis $2757 \mathrm{~m}$ from mean sea level. Relative relief map was developed from the contour map which digitized from SOI topographic sheets at the scale of 1:50,000. Reclassify tool of GIS has been used for reclassification of relative relief map into four classes (656-1190m, 1191-1581m, 1582-2041m, 2042-2757m) on the basis of slope failure occurrences, type and size in relative reliefs (Figure $4 \mathrm{k}$ ).

\section{(l) Curvature}

Curvature is the intersection of random planes with surface (Ramesh and Anbazhagan 2015). Frictional and cohesion forces act differently in different types of surfaces. Inflow and outflow of water or drainage systems is controlled by these surfaces. Flat, Convex and Concave surfaces are normally found in hilly terrain which plays important role in erosion and weathering processes of slopes. Curvature map was developed from the digital elevation model (DEM) of the region (1:50,000) and classified into three classes (Flat, Convex and Concave) Figure 4(1).

\section{Results and Discussion}

\section{(a) Landslide hazard zonation using analytical hierarchy process (AHP) method}

Landslide hazard zonation maps are prepared with impact from different causative factor maps on the scale of 1:10,000 in GIS environment. Digital elevation model of study area is obtained after the conversion of vector data (point, line and polygon) into raster data and reclassification of all factors (pixels $10 \times 10 \mathrm{~m}$ )have been done. The weight values of factors are obtained through analysis of raster data model by using pair wise comparison matrix. Raster data model helps in the analysis of landslide hazard index (LHI) values for development of landslide hazard zonation maps (Figure 5a). Landslide hazard index (LHI) values were analyzed through multiplication of subclass weightage of factors to the factor weightage based on equation 8 .

Weight values of analytical hierarchy process (AHP) are shown in table 4 after normalization of all subclasses of causative factors. Ratio of all subclass causative factors average values and total number of subclass in each factor are used for the normalization of all AHP weight values. Excel sheets are used for analysis of consistency index values and table 4 helps in calculation of random index values. Slope gradient is one of the important causative factor which is responsible for landslide incidences. AHP weight values in the case of steeper slopes between $60^{\circ}$ $80^{\circ}$ has high values of 0.527 followed by lesser slopes while lowest slope angle between 0 - $15^{\circ}$ have lesser AHP weight values of 0.048 . Slopes of hills facing in the direction of north west (conglomerate boulders) 0.362 and south 
west (sandstones) 0.233 have high AHP weight values while slopes which facing south and east directions have less AHP weight value
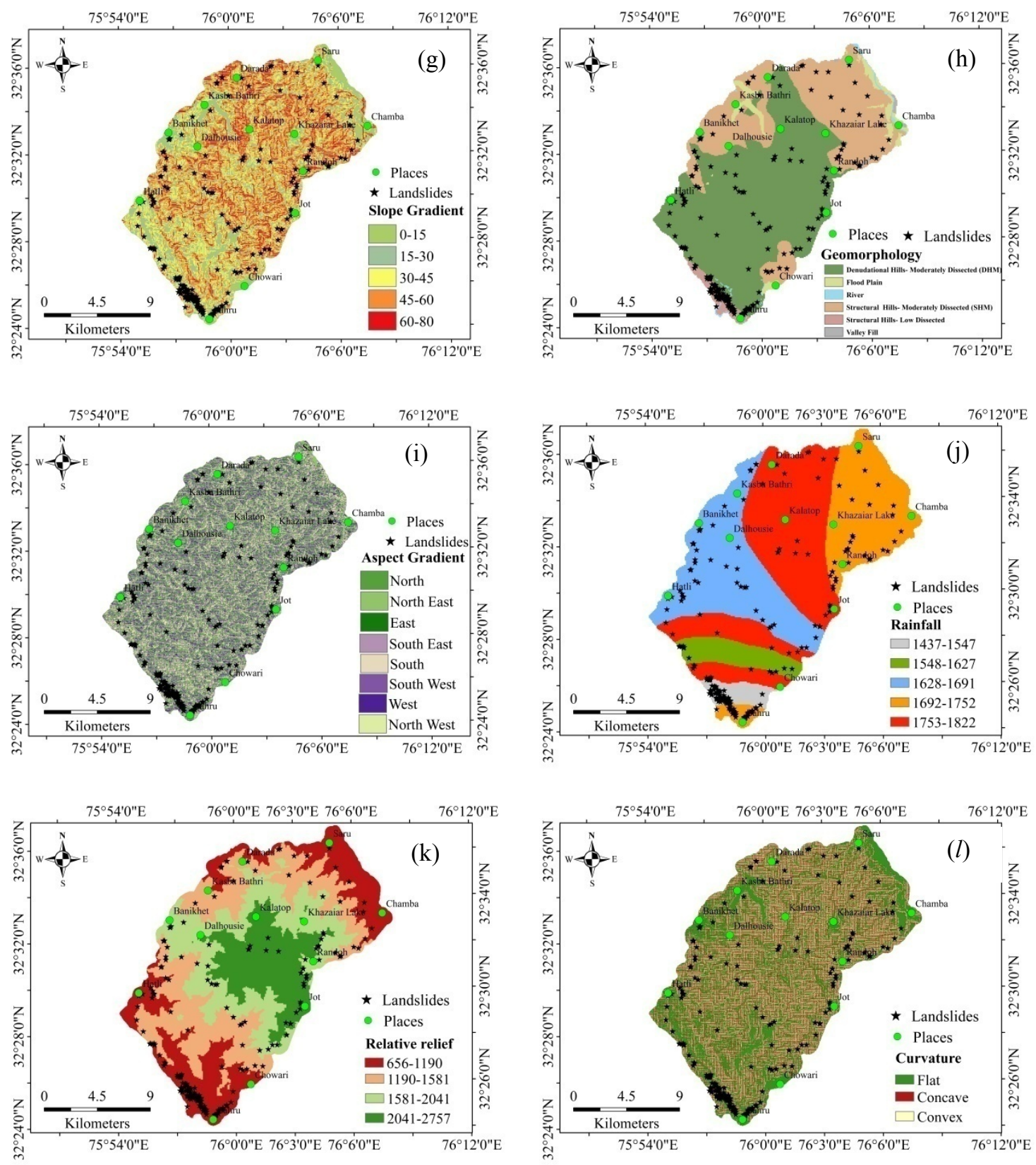

Figure 4 (Continued...):Thematic data layers (g) Slope gradient map, (h) Geomorphology map, (i) Aspect map (j) Rainfall map (k) Relative relief map ( $l$ ) Curvature map.

Conditions of landslide hazards is also affected by density of drainage networks and lineaments. In the study area very low and low classes of lineament $(0.080,0.77)$ and drainage density $(0.067,0.076)$ have less impact on landslide incidences respectively. High density of lineament $(0.618)$ and drainage networks $(0.608)$ have high impact followed by moderate class of both factors $(0.226$ and 0.216$)$. In the case of relative relief, high altitude (2042-2757m) of terrain is highly effected by landslide resulted high AHP value of 0.606 followed by less (1582$2041 \mathrm{~m}$ ) altitude of terrains with less number of landslides $(0.229)$ while $656-1190 \mathrm{~m}$ of altitude have average of least number of landslides with AHP value 0.054. Geomorphology of the terrain classified into six categories in which low dissected structural hills (0.326) are most effected by slope failures due to exposure for weathering processes 
followed by moderately dissected denudation hills $(0.31)$ and moderate dissected structural hills $(0.199)$. Land covered by shrub have high AHP value $(0.235)$ followed by road $(0.183)$ and settlement $(0.134)$ while other classes of LULC have less AHP values. Moisture containment play very important role in formation of slope curvatures. Flat type of slope surfaces have lesser AHP value of 0.083 other than concave $(0.723)$ and convex $(0.194)$ curvature type of land surfaces. Rainfall in the study area given the 0.606, 0.216, 0.091and 0.042 AHP values for 1692$1752 \mathrm{~mm}, 1628-1691 \mathrm{~mm}, 1548-1627 \mathrm{~mm}$ and $1437-1547 \mathrm{~mm}$ classes respectively. Conglomerate boulders of upper Siwalik formation (0.315) most affected areas of the study area which followed by sandstones with shale of Dharamsala formation (0.153) while clay boulders and sand of alluvium formation (0.026), slate, phylite, carbonaceous and quartzite of Chamba formation (0.022) and micaceous granite of Dalhousie formation have least AHP values. Among all the factors soil is important factor for incidences of slope failures. The outcome of all subclasses comparison of soil, coarse loamy soil have highest AHP value of 0.545 followed by loamy skeletal soil 0.162. Equation 5 was used for the delineation of landslide hazard index values, very low (2.95\%), low (4.27\%), moderate $(24.40 \%)$, high $(31.03 \%)$ and very high $(40.30 \%)$ classes of landslide hazard zones were obtained respectively from classification of landslide hazard index values by using natural break system. AHP based LHZ map was delineated by modest form of the landslide hazard index equation 5 in GIS environment which can be written as:

$$
\begin{aligned}
L H I_{A H P} & =\left(S G_{A H P} \times 0.09\right)+\left(\mathrm{AG}_{\mathrm{AHP}} \times 0.07\right)+\left(\mathrm{LC}_{\mathrm{AHP}} \times 0.08\right)+\left(\mathrm{Geom}_{\mathrm{AHP}} \times 0.08\right)+\left(\mathrm{RR}_{\mathrm{AHP}} \times 0.018\right)+\left(\mathrm{Soil}_{\mathrm{AHP}} \times 0.08\right) 8 \\
& +\left(\mathrm{Lith}_{\mathrm{AHP}} \times 0.07\right)+\left(\mathrm{LD}_{\mathrm{AHP}} \times 0.012\right)+\left(\mathrm{DD}_{\mathrm{AHP}} \times 0.018\right)+\left(\operatorname{Rain}_{A H P} \times 0.012\right)+\left(\operatorname{Curv}_{\mathrm{AHP}} \times 0.02\right)
\end{aligned}
$$

Landslide hazard index (LHI) values were determined through AHP model between $0.03748-0.30000$. Maximum area of very high, high and moderate hazard zones of landslides are prevailing in south east (Lahru, Banikhet and Dalhousie) and south west (Lahru) direction of selected examined area of Chamba district while very low and low hazard zones lies near Chamba city in north direction of the study area. Mostly very high and high hazard zones lies near lineament density high and exposed land cover for erosion and weathering processes while very low and low hazard zones are located near water bodies, densely vegetated covered and flood plains. It can be clearly observed that $71.33 \%$ of high and very high hazard zones are covered while moderate $24.40 \%$, low $4.27 \%$ and very low $2.95 \%$ hazard zones are covered respectively (Figure $4 \mathrm{c}$ ). Density of landslides also increases while frequency of landslides has increased. Consistency index (CI) values are calculated for the weight values accuracy of all factors subclass through the MS excel sheet and random index values obtained from table 3. Consistency ratio (CR) value 0.074 is obtained for the weight value of prevailing factor for pair through pairwise comparison (equation 2).

\begin{tabular}{|c|c|c|c|c|c|c|c|c|c|c|c|c|}
\hline Factors & 1 & 2 & 3 & 4 & 5 & 6 & 7 & 8 & 9 & 10 & 11 & $\begin{array}{c}\text { Normalized } \\
\text { Weight }\left(\mathbf{W}_{\text {ik }}\right)\end{array}$ \\
\hline Slope Gradient $\left({ }^{\circ}\right)$ & 1 & 5 & 1 & 0.5 & 2 & 0.14 & 0.11 & 1 & 0.14 & 5 & 3 & 0.062 \\
\hline Aspect Gradient & 0.2 & 1 & 0.25 & 0.25 & 0.5 & 0.2 & 0.2 & 0.14 & 0.2 & 1 & 1 & 0.024 \\
\hline Soil & 1 & 4 & 1 & 0.5 & 3 & 0.2 & 0.2 & 0.33 & 0.17 & 2 & 2 & 0.052 \\
\hline Lithology & 2 & 4 & 2 & 1 & 2 & 0.33 & 0.5 & 1 & 0.2 & 5 & 2 & 0.078 \\
\hline Geomorphology & 0.5 & 2 & 0.33 & 0.5 & 1 & 0.5 & 0.14 & 1 & 0.14 & 5 & 2 & 0.049 \\
\hline LULC & 7 & 5 & 5 & 3 & 2 & 1 & 0.5 & 3 & 0.5 & 5 & 2 & 0.149 \\
\hline Rainfall & 9 & 5 & 5 & 2 & 7 & 2 & 1 & 3 & 1 & 9 & 7 & 0.222 \\
\hline Lineament Density & 1 & 7 & 3 & 1 & 1 & 0.33 & 0.33 & 1 & 1 & 4 & 5 & 0.101 \\
\hline Drainage Density & 7 & 5 & 6 & 5 & 7 & 2 & 1 & 1 & 1 & 6 & 5 & 0.211 \\
\hline Relative Relief & 0.2 & 1 & 0.5 & 0.2 & 0.2 & 0.2 & 0.11 & 0.25 & 0.17 & 1 & 0.33 & 0.02 \\
\hline Curvature & 0.33 & 1 & 0.5 & 0.5 & 0.5 & 0.5 & 0.14 & 0.2 & 0.2 & 3 & 1 & 0.033 \\
\hline Consistency Ratio & 0.07 & & & & & & & & & & & \\
\hline \multicolumn{13}{|c|}{ Comparison of factor classes } \\
\hline Slope Gradient $\left({ }^{\circ}\right)$ & & & & & & & & & & & & $\mathbf{W}_{\mathrm{ik}}$ \\
\hline $0-15$ & 1 & & & & & & & & & & & 0.048 \\
\hline $15-30$ & 1 & 1 & & & & & & & & & & 0.052 \\
\hline $30-45$ & 3 & 2 & 1 & & & & & & & & & 0.124 \\
\hline $45-60$ & 5 & 5 & 2 & 1 & & & & & & & & 0.249 \\
\hline $60-80$ & 7 & 7 & 7 & 3 & 1 & & & & & & & 0.527 \\
\hline Consistency Ratio & 0.09 & & & & & & & & & & & \\
\hline \multicolumn{13}{|l|}{ Aspect Gradient } \\
\hline North East & 1 & & & & & & & & & & & 0.115 \\
\hline
\end{tabular}

Table 4: Analysis of thematic layers and subclasses causative factor 


\begin{tabular}{|c|c|c|c|c|c|c|c|c|c|c|}
\hline East & 0.33 & 1 & & & & & & & & 0.044 \\
\hline South East & 1 & 5 & 1 & & & & & & & 0.109 \\
\hline South & 0.33 & 1 & 0.33 & 1 & & & & & & 0.042 \\
\hline South West & 5 & 5 & 2 & 5 & 1 & & & & & 0.233 \\
\hline West & 0.25 & 1 & 1 & 1 & 0.2 & 1 & & & & 0.05 \\
\hline North West & 7 & 5 & 7 & 7 & 2 & 5 & 1 & & & 0.362 \\
\hline North & 0.25 & 1 & 0.33 & 1 & 0.2 & 1 & 0.2 & 1 & & 0.045 \\
\hline Consistency Ratio & \multicolumn{10}{|l|}{0.07} \\
\hline \multicolumn{11}{|l|}{ Land Cover } \\
\hline Sparse Vegetation & 1 & & & & & & & & & 0.033 \\
\hline Settlement & 5 & 1 & & & & & & & & 0.134 \\
\hline Forest & 0.33 & 0.2 & 1 & & & & & & & 0.024 \\
\hline Agriculture Land & 5 & 0.5 & 3 & 1 & & & & & & 0.077 \\
\hline Shrub & 5 & 4 & 6 & 2 & 1 & & & & & 0.235 \\
\hline Rocky Terrain & 7 & 0.33 & 3 & 1 & 0.25 & 1 & & & & 0.107 \\
\hline Road & 9 & 2 & 5 & 5 & 0.5 & 1 & 1 & & & 0.183 \\
\hline Khazaiar Lake & 1 & 0.25 & 5 & 1 & 0.33 & 0.25 & 0.25 & 1 & & 0.056 \\
\hline River & 2 & 0.2 & 2 & 0.5 & 0.2 & 0.33 & 0.2 & 1 & 1 & 0.040 \\
\hline Consistency Ratio & \multicolumn{10}{|l|}{0.08} \\
\hline \multicolumn{11}{|l|}{ Geomorphology } \\
\hline $\begin{array}{l}\text { Structural Hills - } \\
\text { Moderately (SHM) } \\
\text { Dissected }\end{array}$ & 1 & & & & & & & & & 0.199 \\
\hline $\begin{array}{l}\text { Structural Hills- Low } \\
\text { Dissected }\end{array}$ & 2 & 1 & & & & & & & & 0.326 \\
\hline $\begin{array}{l}\text { Denudational Hills - } \\
\text { Moderately Dissected } \\
\text { (DHM) }\end{array}$ & 2 & 1 & 1 & & & & & & & 0.31 \\
\hline River & 0.17 & 0.2 & 0.25 & 1 & & & & & & 0.056 \\
\hline Flood Plain & 0.2 & 0.14 & 0.2 & 1 & 1 & & & & & 0.051 \\
\hline Valley Fill & 0.33 & 0.17 & 0.14 & 1 & 1 & 1 & & & & 0.058 \\
\hline Consistency Ratio & \multicolumn{10}{|l|}{0.08} \\
\hline \multicolumn{11}{|l|}{ Relative Relief } \\
\hline $656-1190$ & 1 & & & & & & & & & 0.054 \\
\hline $1191-1581$ & 3 & 1 & & & & & & & & 0.112 \\
\hline $1582-2041$ & 5 & 4 & 1 & & & & & & & 0.229 \\
\hline $2042-2757$ & 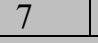 & 5 & 7 & 1 & & & & & & 0.606 \\
\hline Consistency Ratio & \multicolumn{10}{|c|}{0.018} \\
\hline \multicolumn{11}{|l|}{ Soil } \\
\hline Sandy skeletal soil & 1 & & & & & & & & & 0.147 \\
\hline Loamy skeletal soil & 2 & 1 & & & & & & & & 0.162 \\
\hline $\begin{array}{l}\text { Loamy skeletal soil } \\
\text { with loamy surface }\end{array}$ & 0.14 & 0.2 & 1 & & & & & & & 0.03 \\
\hline Loamy soil & 0.5 & 0.33 & 3 & 1 & & & & & & 0.076 \\
\hline $\begin{array}{l}\text { Calcareous loamy } \\
\text { soil }\end{array}$ & 5 & 9 & 9 & 9 & 1 & & & & & 0.545 \\
\hline Rocky outcrops & 0.2 & 0.2 & 2 & 0.3 & 0.11 & 1 & & & & 0.041 \\
\hline Consistency Ratio & \multicolumn{10}{|l|}{0.08} \\
\hline \multicolumn{11}{|l|}{ Lithology } \\
\hline $\begin{array}{l}\text { Alluvium } \\
\text { (Clay boulder and sand) }\end{array}$ & 1 & & & & & & & & & 0.026 \\
\hline $\begin{array}{l}\text { Chamba formation } \\
\text { (Slate, carbonaceous }\end{array}$ & 1 & 1 & & & & & & & & 0.022 \\
\hline
\end{tabular}




\begin{tabular}{|c|c|c|c|c|c|c|c|c|c|c|c|c|}
\hline \multicolumn{13}{|l|}{ phyllite and quartzite) } \\
\hline $\begin{array}{l}\text { Dalhousie Granite } \\
\text { (Micaceousgranite) }\end{array}$ & 1 & 1 & 1 & & & & & & & & & 0.021 \\
\hline $\begin{array}{l}\text { Dharmsalaformation } \\
\text { (Sandstone with shale) }\end{array}$ & 3 & 7 & 7 & 1 & & & & & & & & 0.153 \\
\hline $\begin{array}{l}\text { Ghar formation } \\
\text { (Paragneisses) }\end{array}$ & 5 & 5 & 3 & 0.2 & 1 & & & & & & & 0.056 \\
\hline $\begin{array}{l}\text { Khalelformation } \\
\text { (Lilang Group- } \\
\text { Limestone with } \\
\text { calcareous shale and } \\
\text { ferruginous chert) }\end{array}$ & 5 & 3 & 5 & 1 & 5 & 1 & & & & & & 0.106 \\
\hline $\begin{array}{l}\text { Khokanformation } \\
\text { (Chlorite, mica schist, } \\
\text { slate and quartzite) }\end{array}$ & 7 & 5 & 7 & 0.5 & 3 & 1 & 1 & & & & & 0.105 \\
\hline $\begin{array}{l}\text { Mandiformation } \\
\text { (Mandivolcanoes) }\end{array}$ & 7 & 7 & 5 & 0.33 & 5 & 1 & 1 & 1 & & & & 0.109 \\
\hline $\begin{array}{l}\text { Pindruformation } \\
\text { (Interstratified schist's } \\
\text { and quartzite) }\end{array}$ & 1 & 5 & 7 & 0.2 & 3 & 0.33 & 0.33 & 0.33 & 1 & & & 0.065 \\
\hline River & 1 & 1 & 1 & 0.2 & 0.2 & 0.2 & 0.2 & 0.2 & 0.2 & 1 & & 0.022 \\
\hline $\begin{array}{l}\text { Upper } \\
\text { Siwaliks(Boulder } \\
\text { Conglomerate) }\end{array}$ & 7 & 7 & 7 & 2 & 7 & 7 & 7 & 7 & 7 & 7 & 1 & 0.315 \\
\hline Consistency Ratio & \multicolumn{12}{|l|}{0.07} \\
\hline \multicolumn{13}{|l|}{ Lineament Density } \\
\hline Very low & 1 & & & & & & & & & & & 0.080 \\
\hline Low & 2 & 1 & & & & & & & & & & 0.077 \\
\hline Moderate & 3 & 3 & 1 & & & & & & & & & 0.226 \\
\hline High & 7 & 8 & 3 & 1 & & & & & & & & 0.618 \\
\hline Consistency Ratio & \multicolumn{12}{|l|}{0.012} \\
\hline \multicolumn{13}{|l|}{ Drainage Density } \\
\hline Very low & 1 & & & & & & & & & & & 0.067 \\
\hline Low & 2 & 1 & & & & & & & & & & 0.076 \\
\hline Moderate & 4 & 3 & 1 & & & & & & & & & 0.216 \\
\hline High & 9 & 7 & 4 & 1 & & & & & & & & 0.643 \\
\hline \multicolumn{13}{|l|}{ Rainfall } \\
\hline $1437-1547$ & 1 & & & & & & & & & & & 0.042 \\
\hline $1548-1627$ & 3 & 1 & & & & & & & & & & 0.091 \\
\hline $1628-1691$ & 8 & 3 & 1 & & & & & & & & & 0.261 \\
\hline $1692-1752$ & 9 & 9 & 3 & 1 & & & & & & & & 0.606 \\
\hline Consistency Ratio & \multicolumn{12}{|l|}{0.012} \\
\hline \multicolumn{13}{|l|}{ Curvature } \\
\hline Flat & 1 & & & & & & & & & & & 0.083 \\
\hline Convex & 3 & 1 & & & & & & & & & & 0.194 \\
\hline Concave & 7 & 5 & 1 & & & & & & & & & 0.723 \\
\hline Consistency Ratio & \multicolumn{12}{|l|}{0.02} \\
\hline
\end{tabular}

\section{(b) Landslide hazard zonation using information value method}

Analysis of correlation between slope failure locations and thematic layers (slope gradient, slope aspect, lithology, lineament density, geomorphology, drainage density, rainfall, soil, land use/ cover, relative relief and curvature) were executed through combine tool in GIS environment for information value method. Landslide hazard zonation map has been delineated based on equation 9 with the help of map algebra tool and raster calculator. 
372 Table 5: Spatial relationship between each factor causing landslide and landslide using the information value model

\begin{tabular}{|c|c|c|c|c|c|c|c|}
\hline Factors & Class & $\mathbf{N}_{\mathbf{C L} \_} \mathbf{P i x}$ & $\mathrm{N}_{\mathrm{SL}} \mathbf{P} \mathbf{P i x}$ & $\begin{array}{l}\text { Conditional } \\
\text { Probability } \\
\left(C_{p}\right)\end{array}$ & $\begin{array}{l}\text { Priority } \\
\text { Probabili } \\
\text { ty }\left(P_{p}\right)\end{array}$ & $\mathbf{C}_{\mathrm{p}} / \mathbf{P}_{\mathrm{p}}$ & $\begin{array}{l}\text { Informatio } \\
\text { n Weight } \\
\text { Value } \\
\text { (IVM) }\end{array}$ \\
\hline \multirow[t]{5}{*}{ Slope } & $0-15$ & 597082 & 0 & 0 & 0.001444 & 0 & 0 \\
\hline & $15-30$ & 519151 & 764 & 0.001472 & 0.001444 & 1.02 & 0.008 \\
\hline & $30-45$ & 608521 & 918 & 0.001509 & 0.001444 & 1.05 & 0.019 \\
\hline & $45-60$ & 638257 & 1039 & 0.001628 & 0.001444 & 1.13 & 0.052 \\
\hline & $60-80$ & 372536 & 1229 & 0.003299 & 0.001444 & 2.28 & 0.359 \\
\hline \multirow{8}{*}{$\begin{array}{l}\text { Aspect } \\
\text { Gradient }\end{array}$} & North east & 263230 & 414 & 0.001573 & 0.001444 & 1.08 & 0.037 \\
\hline & East & 79738 & 24 & 0.000301 & 0.001444 & 0.21 & -0.681 \\
\hline & South east & 364840 & 768 & 0.002105 & 0.001444 & 1.46 & 0.164 \\
\hline & South & 322945 & 55 & 0.00017 & 0.001444 & 0.12 & -0.928 \\
\hline & South west & 337057 & 1333 & 0.003955 & 0.001444 & 2.74 & 0.437 \\
\hline & West & 335608 & 7 & 0.0000209 & 0.001444 & 0.014 & -1.84 \\
\hline & North west & 369205 & 1302 & 0.003526 & 0.001444 & 2.44 & 0.388 \\
\hline & North & 662924 & 47 & 0.0000709 & 0.001444 & 0.05 & -1.309 \\
\hline \multirow[t]{11}{*}{ Lithology } & $\begin{array}{l}\text { Alluvium } \\
\text { (Clay boulder and sand) }\end{array}$ & 95316 & 0 & 0 & 0.001444 & 0 & 0 \\
\hline & $\begin{array}{l}\text { Chamba formation } \\
\text { (Slate, phyllite, } \\
\text { carbonaceous and } \\
\text { quartzite) }\end{array}$ & 9769 & 0 & 0 & 0.001444 & 0 & 0 \\
\hline & $\begin{array}{l}\text { Dalhousie granite } \\
\text { (Micaceous granite) }\end{array}$ & 75902 & 0 & 0 & 0.001444 & 0 & 0 \\
\hline & $\begin{array}{l}\text { Dharmsala formation } \\
\text { (Sandstone with shale) }\end{array}$ & 177997 & 574 & 0.003225 & 0.001444 & 2.23 & 0.349 \\
\hline & $\begin{array}{l}\text { Gharformation } \\
\text { (Paragneisses) }\end{array}$ & 326207 & 14 & 0.0000429 & 0.001444 & 0.02 & -1.527 \\
\hline & $\begin{array}{l}\text { Khalel formation } \\
\text { (Lilang group- limestone } \\
\text { with calcareous shale and } \\
\text { ferruginous chert) }\end{array}$ & 30528 & 62 & 0.002031 & 0.001444 & 1.4 & 0.148 \\
\hline & $\begin{array}{l}\text { Khokan formation } \\
\text { (Chlorite, mica schist, } \\
\text { slate and quartzite) }\end{array}$ & 767634 & 200 & 0.000261 & 0.001444 & 0.18 & -0.744 \\
\hline & $\begin{array}{l}\text { Mandi formation } \\
\text { (Mandi volcanoes) }\end{array}$ & 342393 & 676 & 0.001974 & 0.001444 & 1.37 & 0.136 \\
\hline & $\begin{array}{l}\text { Pindru formation } \\
\text { (Interstratified schists } \\
\text { and quartzite) }\end{array}$ & 829363 & 376 & 0.000453 & 0.001444 & 0.31 & -0.503 \\
\hline & River & 19345 & 17 & 0.000879 & 0.001444 & 0.6 & -0.216 \\
\hline & $\begin{array}{l}\text { Upper Siwaliks } \\
\text { (Boulder conglomerate) }\end{array}$ & 61093 & 2031 & 0.033244 & 0.001444 & 23.02 & 1.362 \\
\hline \multirow{4}{*}{$\begin{array}{l}\text { Drainage } \\
\text { Density }\end{array}$} & Low & 254298 & 409 & 0.001608 & 0.001444 & 0.9 & -0.047 \\
\hline & Moderate & 783874 & 1199 & 0.00153 & 0.001444 & 0.94 & -0.025 \\
\hline & High & 830755 & 1848 & 0.002224 & 0.001444 & 0.65 & -0.188 \\
\hline & Very High & 866620 & 494 & 0.00057 & 0.001444 & 2.53 & 0.404 \\
\hline \multirow[t]{4}{*}{$\begin{array}{l}\text { Geomorp- } \\
\text { hology }\end{array}$} & $\begin{array}{l}\text { Structural hills- } \\
\text { moderately dissected } \\
\text { (SHM) }\end{array}$ & 935614 & 438 & 0.000468 & 0.001444 & 0.32 & -0.489 \\
\hline & $\begin{array}{l}\text { Structural hills- low } \\
\text { dissected }\end{array}$ & 61221 & 2049 & 0.033469 & 0.001444 & 23.18 & 1.365 \\
\hline & $\begin{array}{l}\text { Denudational hills- } \\
\text { moderately dissected } \\
\text { (DHM) }\end{array}$ & 1613900 & 1463 & 0.000906 & 0.001444 & 0.63 & -0.202 \\
\hline & River & 19473 & 0 & 0 & 0.001444 & 0 & 0 \\
\hline
\end{tabular}




\begin{tabular}{|c|c|c|c|c|c|c|c|}
\hline & Flood plain & 95444 & 0 & 0 & 0.001444 & 0 & 0 \\
\hline & Valley fill & 9895 & 0 & 0 & 0.001444 & 0 & 0 \\
\hline \multirow{4}{*}{$\begin{array}{l}\text { Lineament } \\
\text { Density }\end{array}$} & Very low & 266883 & 1350 & 0.005058 & 0.001444 & 0.29 & -0.545 \\
\hline & Low & 711703 & 1471 & 0.002067 & 0.001444 & 0.7 & -0.156 \\
\hline & Moderate & 999906 & 621 & 0.000621 & 0.001444 & 2.32 & 0.366 \\
\hline & High & 757055 & 508 & 0.000671 & 0.001444 & 2.15 & 0.333 \\
\hline \multirow[t]{6}{*}{ Soil } & $\begin{array}{l}\text { Loamy skeletal soil with } \\
\text { loamy surface }\end{array}$ & 488350 & 51 & 0.000104 & 0.001444 & 0.07 & -1.141 \\
\hline & Loamy skeletal soil & 970307 & 443 & 0.000457 & 0.001444 & 0.32 & -0.5 \\
\hline & Rocky outcrops & 131122 & 0 & 0 & 0.001444 & 0 & 0 \\
\hline & Loamy soil & 508273 & 235 & 0.000462 & 0.001444 & 0.32 & -0.495 \\
\hline & Sandy skeletal soil & 542058 & 3221 & 0.005942 & 0.001444 & 4.11 & 0.614 \\
\hline & Coarse loamy soil & 95437 & 0 & 0 & 0.001444 & 0 & 0 \\
\hline \multirow{9}{*}{$\begin{array}{l}\text { Land Use/ } \\
\text { Cover }\end{array}$} & River & 26971 & 0 & 0 & 0.001444 & 0 & 0 \\
\hline & Sparse vegetation & 376062 & 1004 & 0.00267 & 0.001444 & 1.85 & 0.266 \\
\hline & Settlement & 92669 & 1178 & 0.012712 & 0.001444 & 8.8 & 0.945 \\
\hline & Forest & 1266924 & 84 & $6.63 \mathrm{E}-05$ & 0.001444 & 0.04 & -1.338 \\
\hline & Agriculture land & 535376 & 724 & 0.001352 & 0.001444 & 0.94 & -0.028 \\
\hline & Shrub & 269982 & 549 & 0.002033 & 0.001444 & 1.41 & 0.149 \\
\hline & Rocky terrain & 148181 & 327 & 0.002207 & 0.001444 & 1.53 & 0.184 \\
\hline & Road & 19174 & 84 & 0.004381 & 0.001444 & 3.03 & 0.482 \\
\hline & Khajiar Lake & 208 & 0 & 0 & 0.001444 & 0 & 0 \\
\hline \multirow[t]{4}{*}{ Rainfall } & $1437-1547$ & 89859 & 582 & 0.006477 & 0.001444 & 0.22 & -0.652 \\
\hline & $1548-1627$ & 629317 & 1527 & 0.002426 & 0.001444 & 0.6 & -0.225 \\
\hline & $1628-1691$ & 951594 & 347 & 0.000365 & 0.001444 & 3.96 & 0.598 \\
\hline & $1692-1752$ & 1064777 & 1494 & 0.001403 & 0.001444 & 1.03 & 0.012 \\
\hline \multirow{4}{*}{$\begin{array}{l}\text { Relative } \\
\text { Relief }\end{array}$} & $656-1190$ & 681747 & 1186 & 0.00174 & 0.001444 & 0.83 & -0.08 \\
\hline & $1190-1581$ & 868767 & 1760 & 0.002026 & 0.001444 & 0.71 & -0.147 \\
\hline & 1581-2041 & 696372 & 537 & 0.000771 & 0.001444 & 1.87 & 0.272 \\
\hline & $2041-2757$ & 488661 & 467 & 0.000956 & 0.001444 & 1.51 & 0.179 \\
\hline \multirow[t]{3}{*}{ Curvature } & Flat & 152199 & 0 & 0 & 0.001444 & 0 & 0 \\
\hline & Convex & 1283651 & 1094 & 0.000852 & 0.001444 & 0.59 & -0.229 \\
\hline & Concave & 1299697 & 2856 & 0.002197 & 0.001444 & 1.52 & 0.182 \\
\hline
\end{tabular}

Weight value of slope gradient classes demonstrates the increasing order of weights from $15^{\circ}$ to $80^{\circ}$ where, 0.359 weight for $60^{\circ}$ to $80^{\circ}$ slope is highest weight value followed by $0.052\left(45^{\circ}\right.$ to $\left.60^{\circ}\right), 0.019\left(30^{\circ}-45^{\circ}\right)$ and $0.008\left(15^{\circ}\right.$ $30^{\circ}$ ) whereas no landslide was found between the slope angle 0 to $15^{\circ}$ due to flat terrain and river beds. Observation of these weight values clearly shown that number of landslides increased where slope of terrain is high and numbers of landslides are decreased such as slope angle of terrain decreases. The weight of unattached sections of strata and gravity actions were more prominent on inclined slopes in contrast to moderate slopes, but failure of slopes depends upon the strength of shear forces of material, shear strength on inclined slopes are less than moderate slopes resulting inclined slopes are fails early than moderate slopes. In case of slope aspect, the South West (0.437) and North West (0.388) direction facing slopes are the frequently effected by landslides whereas least number of landslides were recorded in the north (-1.309) and west $(-1.840)$ classes of slope aspect due to monsoon follows mostly in north west and south west directions of the region and these regions are exposed for the weathering processes from rainfall and wind. Relative relief of the terrain also play very important role in landslide occurrences, high number of slope displacements are recorded (0.272) in $1581-204 \mathrm{~m}$ and followed by $2041-2757 \mathrm{~m}(0.179)$ while number of slope displacements are recorded in 656-1190m (-0.080) and 1190-1581 (-0.147). In terms of the curvature, flatter surface have zero weight values due to absence of slope and convex slope experienced less weight values $(-0.229)$ due to less number of slope failure incidences while concave slopes are experienced high weight values $(0.182)$ due to high number of slope failure incidences shown in table 5.

In the region where landside frequency high, density of drainage networks would also high (0.333) while where landside frequency very low (-0.545), density of drainage networks would also low. Tributaries and gullies of main rivers are contributed in toe cutting of slopes and bank erosion. Lineaments play an important role for initiating landslides. Planar and toppling such types of slope failures are managed by different types of lineaments such as fault, joint etc. Initiation of landslides are commonly affected by strength and orientation of discontinuities, greater information values were evaluated for high $(-0.188)$ and very high lineament density class (0.404). In case of soil 
map, sandy skeletal soil (0.614) has evidence of maximum number of landslide which was followed by loamy skeletal soil (-0.50). Zero weight value was obtained for rocky outcrops and coarse loamy soil classes due to absence of landslides. Sandy skeletal soil has maximum exposed for weathering process due to river and gullies. Among all factors lithology terrain play very important role. Mainly igneous (Micaceous Granite, Mandi Volcanes- Basaltic and andesitic flows) sedimentary (sandstones, clay, sandstone with shale, limestone with calcareous shale and ferruginous chert, conglomerate boulder) and metamorphic (Slate, Phyllite, Carbonaceous and Quartzite, Paragneisses, Chlorite, Mica Schist, Slate and Quartzite, Interstratified Schists and Quartzite) rocks were found into various formations like Alliuvium, Upper Siwalik, Pindru, Mandi, Khokan, Khalel (Lilang group), Ghar, Dharmsala, Chamba and Dalhousie. There are none evidence of slope failure into Chamba and Dalhousie formation while into upper Siwalik rock formation has high number of slope failures resulted high weight value of 1.362 followed by Khalel and Mandi rock formations. Geomorphology of terrain classified into six various classes like structural hillsmoderately dissected (SHM), structural hills- low dissected, and denudational hills - moderately dissected (DHM), river, flood plains and valley fills. Weight values of low dissected structural hills are analyzed high weight value of 0.326 which followed by moderately dissected denudational $(0.32)$ and structural hills $(0.199)$ while river, flood plain and valley fills are zero weight value due to none presence of landslides. In the case of land use and cover, forest $(-1.338)$ and agriculture lands $(-0.028)$ of region have negative value while slopes which correlated with settlement areas have high weight value 0.945 . Road networks (0.482), sparse vegetation $(0.266)$, rocky terrain $(0.184)$ and shrub $(0.149)$ have also follow the same trend of information weight values. Among all variables rainfall is most important and essential factor which recorded by Indian metrological department from $1437 \mathrm{~mm}$ to 1752 $\mathrm{mm}$. low regions of rainfall $1437-1547 \mathrm{~mm}(-0.652)$ and $1548-1627 \mathrm{~mm}(-0.225)$ have less weight values while high regions of rainfall $1628-1691 \mathrm{~mm}$ has high weight value of 0.598 which followed by $1692-1752 \mathrm{~mm}(0.012)$.

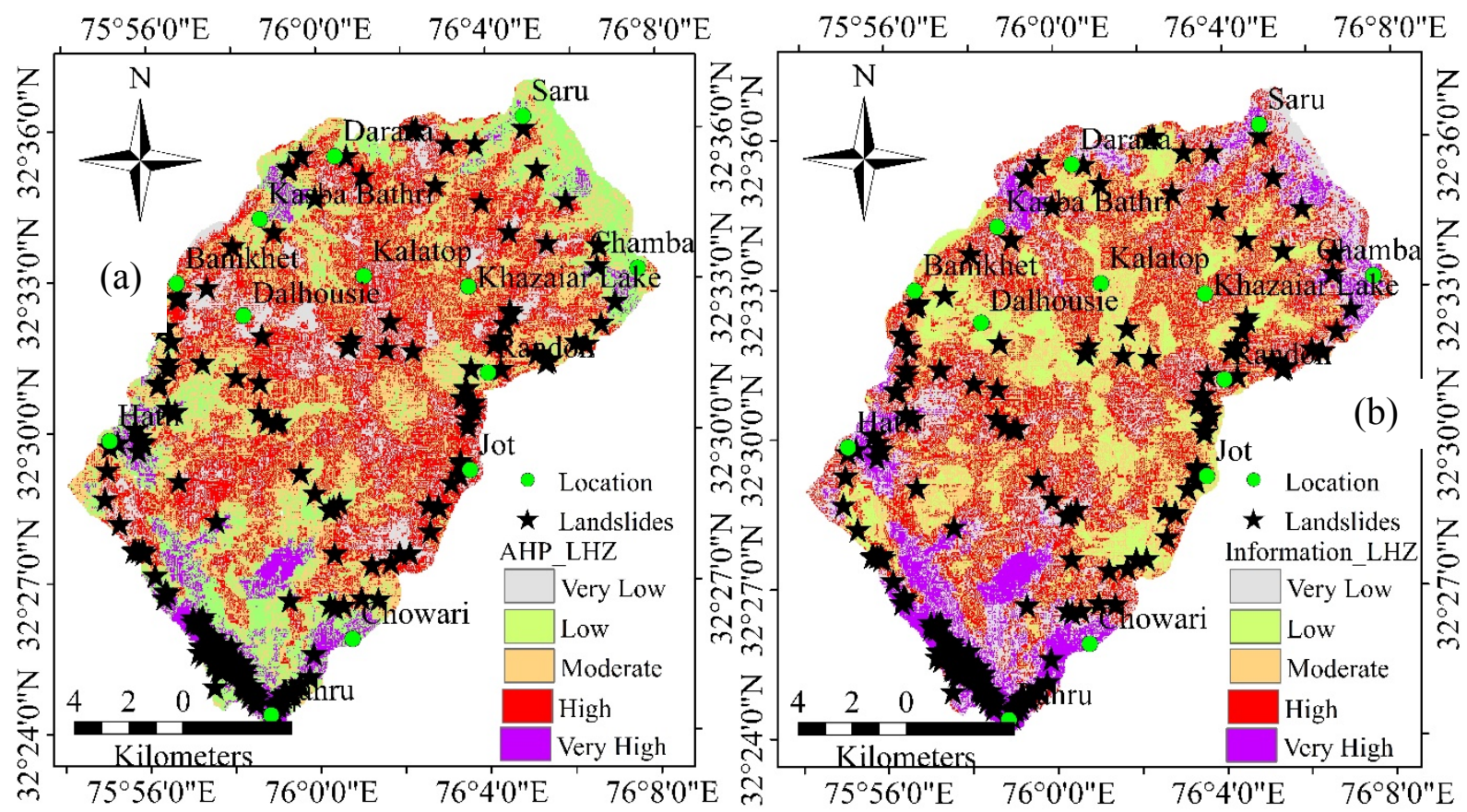

Figure 5: Landslide hazard zonation maps using AHP and Information value methods: (a) Analytical hierarchy process (AHP) hazard map (b) Information value (Inf.V) hazard map

Finally to develop landslide hazard zonation of the region, landslide hazard index values are analyzed from summation of all information weight values by equation 9 . Landslide hazard index values were classified into very low (1.2\%), low (5.31\%), moderate (20.03\%), high (29.26\%) and very high (44.2\%) by using reclassify tool of GIS. 


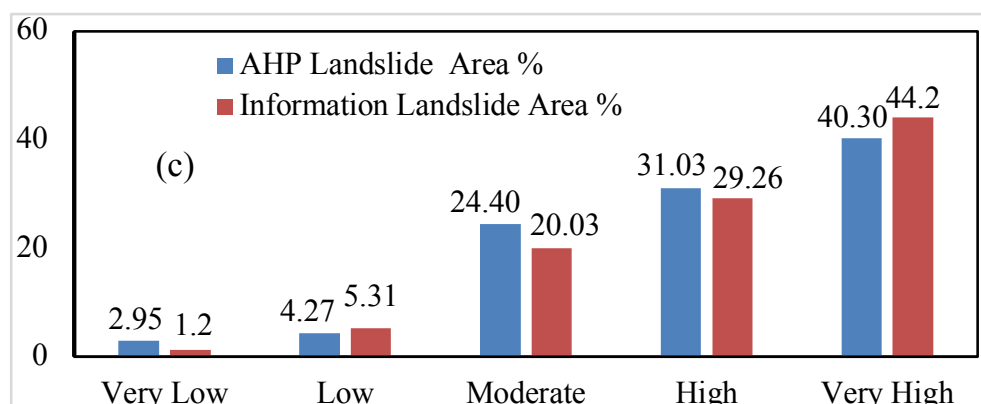

Figure 5 (continued...):(c) Landslide area percentage graph in each landslide hazard zone

\section{VALIDATION}

Very high and high hazard zones were discovered with various types of landslides likely debris flow, rock fall, rock slides and earthy flow in the region. Several researchers suggested that density of landslide in each landslide hazard zone is essential tool for validation of hazard zonation maps (Sarkar and Kanungo 2004). Figure 4(c) shows the comparison of landslide hazard zone classes by AHP and Information value method on the basis of area covered by landslides in each hazard zone. Dissimilarity was observed between the hazard classes of both landslide hazard maps (information value method and AHP). Very low hazard zone occupied 2.95\% and 1.2\% areas in case of AHP and information value method with landslide density (Figure 5c).

Several researchers have proposed the success rate curve method for comparative analysis and validation of hazard maps through analysis of area under curve (Chung and Fabbri 2003; Guzettiet al. 2006; Frattini et al. 2010), the same has been utilized in present study. The LHZ mapswere reclassified into 100 classes using reclassify tool of natural break method in GIS environment for the validation. Pixels of landslides in each class of hazard map were obtained by combining thelandslide inventory raster dataset with the hazard zonation map. Landslide area percentage helps into the analysis of the area under curve, cumulative sum and accuracy of landslides(Figure 6). The success rate for AHP based LHZ map has been calculated as $78.62 \%$ while for information value based LHZ map, it is $85.17 \%$ which is more accurate.

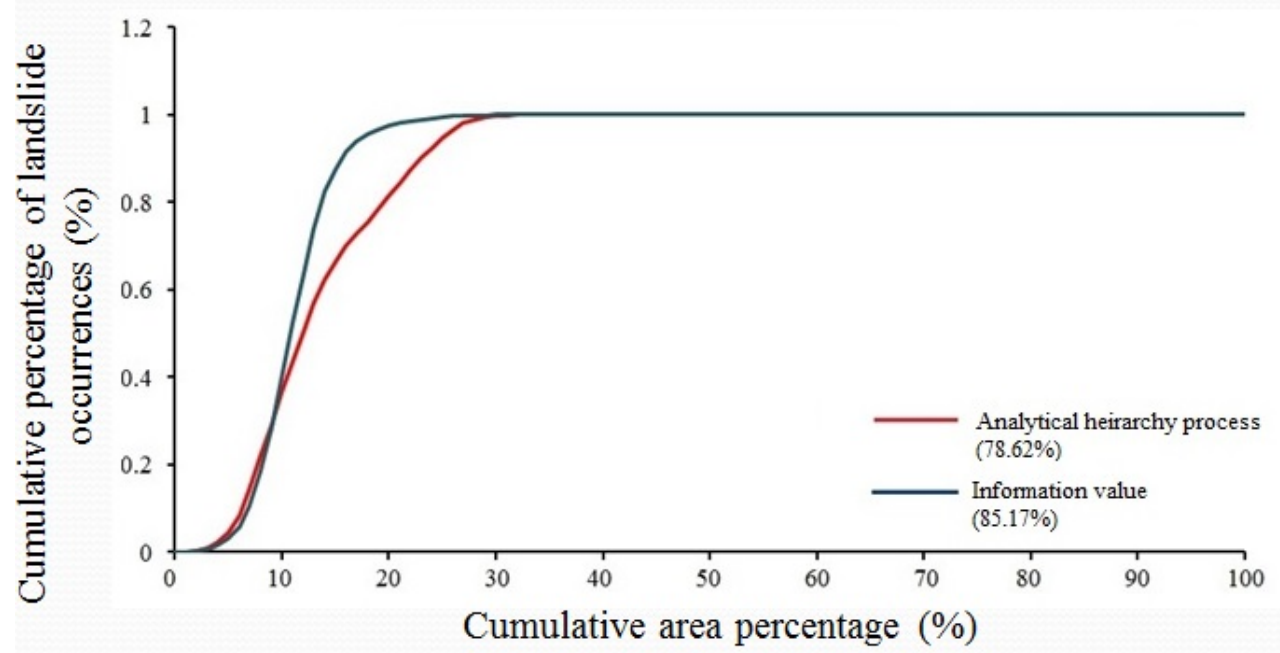

Figure 6: Successive rate curve method for validation of both AHP and Inf.V methods

\section{CONCLUSION}

Himalayan region of India is prominent evidence of most disastrous natural hazards like landslides. Assessment of landslide hazard is essential for Chamba district, Himachal Pradesh, India before any construction such as road (SH-28, NH-154A and link road), reservoirs etc. In the present study, AHP and IV methods were utilized to accomplish hazard zonation of landslides along study area (Lahru to Chamba, Chamba district, Himachal Pradesh). Inventory of different types of landslides were produced from the various sets of data to achieve the objectives of the study. A total of 184 landslides were identified from these data sources. Total eleven various factors (slope gradient, 
slope aspect, relative relief, curvature, lithology, drainage density, lineament density, soil, land use land cover, geomorphology, and rainfall) were identified which play crucial role in the occurrences of slope failures and they were analyzed through AHP and information value method. Weights for each factor class were attributed during the process of modeling. The landslide density as well as success rate curve method was adopted for the validation of the LHZ maps. Density of landslides were increasing in each landslide hazard zone, $6.55 \%$ high prediction rate of information value approach $(85.17 \%)$ is higher than AHP process $(78.62 \%)$ therefore hazard map of landslides obtained from the information value is more accurate than the hazard map of landslides from the AHP.

\section{ACKNOWLEDGEMENT}

The authors are thankful to the Chamba district, Public works department, Himachal Pradesh for providing database of landslide related and Department of Civil Engineering, National Institute of Technology, Hamirpur, Himachal Pradesh for the providing the essential equipment's to conduct the study and also towards the editor and reviewers for their valuable comments and suggestions that helped to improve the quality of paper.

$\begin{array}{ll}\text { ABBREVATION } & \\ \text { GIS } & \text { Geographical Information System } \\ \text { NH } & \text { National Highway } \\ \text { SH } & \text { State Highway } \\ \text { LULC } & \text { Land Use/ Cover } \\ \text { LHEF } & \text { Landslide Hazard evaluation Factor } \\ \text { BIS } & \text { Bureau of Indian Standard } \\ \text { IMD } & \text { Indian meteorological department } \\ \text { VT } & \text { Vaikrita Thrust } \\ \text { MCT } & \text { Main Central Thrust } \\ \text { MBT } & \text { Main Boundary Thrust } \\ \text { LISS } & \text { Linear Imaging Self-Scanning sensor } \\ \text { NRSC } & \text { National Remote Sensing Centre } \\ \text { Inf. V } & \text { Information Value Method } \\ \text { AHP } & \text { Analytical Hierarchy Process } \\ \text { LHI } & \text { Landslide Hazard Index } \\ \text { LHZ } & \text { Landslide Hazard Zonation } \\ \text { SRC } & \text { Successive Rate Curve }\end{array}$

FUNDING

Authors have not received and fund from any agencies and also want to to thanks National Institute of Technology, Hamirpur for allowing using their laboratory and support. Authors have also not have any conflict of interest.

\section{AUTHORS INFORMATION \\ Desh Deepak Pandey, born on July 20, 1987 in Ballia district Uttar Pradesh, India. Working as research scholar in Civil Engineering, National Institute of Technology Hamirpur- 177005. Acquired masters degree in Geo-informatics and Remote Sensing from Bundelkhand University Jhansi, Uttar Pradesh In The Year 2010.}

Dr. R.S. Banshtu, born on June 6, 1963 in Rohuru town, Shimla district Himachal Pradesh, India. Working as Associate Professor in Civil Engineering, National Institute of Technology Hamirpur- 177005. Acquired doctrate degree in Engineering Geology from Punjab University, Chandigarh, Uttar Pradesh in the Year 1992.

The major field of study is Engineering Geology and rock mechanics. Author has twenty years of teaching and research experience in the field of environmental and climate Change.

Kanwarpreet Singh, born on May 11, 1990 in Hoshiarpur district, Punjab, India. Working as Assistant Professor in Civil Engineering, , Mohali, Punjab, India. Acquired doctorate degree in water resources from Civil Engineering, National Institute of Technology, Hamirpur- 177005 in the Year 2020. 
Laxmi Devi Versain, born January 16, 1985 in Dharamshala district, Himachal Pradesh, India. Working as Assistant Professor in Geology department, Government College, Dhaliara, Kangra district Himachal Pradesh. Acquired doctorate degree in Engineering Geology from Civil Engineering, National Institute of Technology,

514 Hamirpur- 177005 in the Year 2020.

\section{REFRENCES}

1. Achour Y, Boumezbeur A, Hadji R, et al. (2017), "Landslide susceptibility mapping using analytic hierarchy process and information value methods along a highway road section in Constantine, Algeria", Arabian journal of geosciences 10: 194.

2. Ahmed F, Rogers JD, Ismail EH (2014), "A regional level preliminary landslide susceptibility study of the upper Indus river basin", European journal of remote sensing 47: 343-373. http://doi.org/10.5721/EUJRS 20144721.

3. Akbar T and Ha S (2011), "Landslide hazard zoning along Himalaya Kahghan Valley of Pakistan-by integration of GPS, GIS, and remote sensing technology", Landslides 8(4): 527-540.

4. Aleotti P, Chowdhury R (1999), "Landslide hazard assessment: summary review and new perspectives", Bulletin of engineering geology and the environment 58(1): 21-44.

5. Anbalgan R (1992), "Landslide hazard evaluation and zonation mapping in mountainous terrain", Engineering geology 32(4): 269-277.

6. Anbalgan R, Kumar R and Lakshmanan K et al. (2015), "Landslide hazard zonation mapping using frequency ratio and fuzzy logic approach, a case study of Lachung Valley, Sikkim", Geo-environmental Disasters 2: 6. https://doi.org/10.1186/ s40677-014-0009-y.

7. Filipello A, Giuliani A, Mandrone G 2010), "Rock slopes failure susceptibility analysis: from remote sensing measurements to geographic information system raster modules,. American journal of environmental sciences (6): 489-494. https://doi. org/10.3844/ajessp.2010.489.494.

8. Ayalew L and Yamagishi H (2005), "The application of GIS based logistic regression for landslide susceptibility mapping in the Kakuda-Yahiko mountains Central Japan", Geomorphology 65(1/2): 15-31.

9. Balsubramani K and Kumaraswamy K (2013), "Application of geospatial technology and information value technique in landslide hazard zonation mapping: a case study of Giri Valley, Himachal Pradesh", Disaster advances 6: 38-47.

10. Blahut J, Van Westen C and Sterlacchini S (2010), "Analysis of landslide inventories for accurate prediction of debris-flow source areas", Geomorphology 119 (1/2): 36-51. https://doi. org/10.1016/j.geomorph.2010.02.017.

11. Chaku SK (1972), "Geology of Chauri Tehsil and adjacent area, Chamba District, H. P.”, Himalayan Geology $2,404-414$.

12. Chang K and Liu J (2004), "Geo-Imagery Bridging continents. Landslide features interpreted by neural network method using a high resolution satellite image and digital topographical data", Proceedings of 20th ISPRS Congress, Istambul.

13. Chen W, Chai H and Zhao Z, et al. (2016), "Landslide susceptibility mapping based on GIS and support vector machine models for the Qianyang County, China", Environment earth sciences 75(6): 1-13.

14. Chung CJF and Fabbri AG (2003), "Validation of spatial prediction models for landslide hazard mapping", Natural hazards 30(3): 451-472. https://doi.org/10.1023/B:NHAZ.0000007172.62651.2b

15. Cruden DM and Varnes DJ (1996), "Landslide types and processes, special report, Transportation Research Board", National academy of sciences 247: 36-75.

16. Dai FC and Lee CF (2002) Landslide characteristics and slope instability modeling using GIS, Lantau Island, Hong Kong. Geomorphology 42(3): 213-228. https://doi.org/10.1016/ S0169-555X(01)00087-3. 
17. Das I, Sahoo S and Van Westen C, et al. (2010), "Landslide susceptibility assessment using logistic regression and its comparison with a rock mass classification system, along a road section in the northern Himalayas (India)", Geomorphology 114(4): 627-637.https://doi.org/10.1016/j.geomorph.2009.09. 023.

18. Deeken A, Thiede RC and Sobel ER, et al. (2011), "Exhumational variability within the Himalaya of northwest India", Earth and planetary science letters 305:103-114. https://doi.org/10.1016/j.epsl.2011.02. 045.

19. Demir G, Aytekin M and Akgun A, et al. (2013), "A comparison of landslide susceptibility mapping of the eastern part of the North Anatolian Fault Zone (Turkey) by likelihood-frequency ratio and analytic hierarchy process methods", Natural Hazards 65: 1481-1506.

20. Ercanoglu M and Gokceoglu C (2004), "Use of fuzzy relations to produce landslide susceptibility map of a landslide prone area (West Black Sea Region, Turkey)", Engineer geology 75: 229-250. https://doi.org/10.1016/j.enggeo.2004.06.001.

21. Fawcett T (2006), “An introduction to ROC analysis", Pattern recognition letters, 27: 861-874.

22. Feizizadeh B and Blaschke T (2012), "GIS-multi-criteria decision analysis for landslide susceptibility mapping: comparing three methods for the Urmia lake basin, Iran”, Natural Hazards 65: 2105-2128.

23. Feizizadeh B, Blaschke $\mathrm{T}$ and Nazmfar H, et al. (2013), "Landslide susceptibility mapping for the Urmia Lake basin, Iran: a multi-criteria evaluation approach using GIS", International journal of environmental research 7(2): 319-3336.

24. Frank W, Grasemann B and Guntli P, et al. (1995) Geological map of the Kishtwar-Chamba-Kulu region (NW Himalaya India)", Jahrbuch der geologischenbundesanstalt 138 (2): 299-308.

25. Frattini P, Crosta G, Carrara A (2010), "Techniques for evaluating the performance of landslide susceptibility models", Engineering Geology 111: 62-72. https://doi.org/10.1016/j. enggeo.2009.12.004.

26. Gomez H, Bradshow R and Mather P (2000), "Monitoring the distribution of shallow landslide prone areas using Remote Sensing, DTM and GIS - a case study from the tropical Andes of Venezuela. In: Casanova E (ed) Remote Sensing in 21st century: Economic and Environmental applications", Balkema, Rotterndam 395-401.

27. Guru B, Veerappan R and Mangminlen T (2016), "Landslide susceptibility zonation mapping using frequency ratio and fuzzy gamma operator models in part of NH-39, Manipur, India", Natural hazards 84: 465-488. https://doi.org/10.1007/s11069-016-2434-6.

28. Guzzetti F (2003), "Landslide Hazard Assessment and Risk Evaluation: Limits and Perspectives", In proceedings of the $4^{\text {th }}$ EGS Plinius conference held at Mallorca, Spain, University de les IllesBalears, Spain. 1-4.

29. Guzzetti F, Carrara A and Cardinali M, et al. (1999), "Landslide hazard evaluation: a review of current techniques and their application in a multi-scale study, Central Italy", Geomorphology 31(1): 181-216. https://doi.org/10.1016/S0169-555X(99)00078-1.

30. Guzzetti F, Reichenbach P and Ardizzone M, et al. (2006), "Estimating the quality of landslides susceptibility models", Geomorphology 81: 166-184. https://doi.org/10.1016/j.geomorph.2006.04.007.

31. Hutchinson JN (1995), "Landslide hazard assessment", In: Proc VI Int. Symp on Landslides, Christchurch 1: 1805-1842.

32. Jaiswal P, Van Westen CJ and Jetten V (2010), "Quantitative landslide hazard assessment along a transportation corridor in southern India”, Engineering geology 116: 236-250.

33. Kanungo DP, Arora MK andSarkar S, et al. (2009) Landslide Susceptibility Zonation (LSZ) Mapping - A Review. Journal of South Asia Disaster Studies 2(1): 81-105.

34. Kavzoglu T, Sahin EK and Colkesen I (2014), "Landslide susceptibility mapping using GIS-based multi-criteria decision analysis, support vector machines and logistic regression", Landslides 11: 425-439. https://doi.org/10.1007/s10346-013-0391-7.

35. Kayastha P, Dhital MR and De Smedt F (2013), “Application of the analytical hierarchy process (AHP) for landslide susceptibility mapping: a case study from the Tinau watershed, west Nepal" Computers and Geosciences 52: 398-408. https://doi.org/10.1016/j.cageo.2012.11.003.

36. Kumar R and Anbalagan R (2016), "Landslide susceptibility mapping using analytical hierarchy process (AHP) in Tehri Reservoir Rim Region, Uttarakhand", Journal geological society of India 87(3): 271-286. https://doi.org/10.1007/s12594-016-0395-8. 
37. Kumar S and Mahajan AK (2001), "Seismo-tectonics of the Kangra region north Himalaya”, Tectonophysics 331(4):359-371.

38. Lee S and Min K (2001), "Statistical analysis of landslide susceptibility at Yongin, Korea", Environmental geology 40(9): 1095-1113.

39. Lee S, Hwang J and Park I (2013), "Application of data-driven evidential belief functions to landslide susceptibility mapping in Jinbu, Korea", Catena 100: 15-30.

40. Sarkar S and Kanungo DP (2004) An integrated approach for landslide susceptibility mapping using remote sensing and GIS. Photogrammetric Engineering and Remote Sensing 70(5): 617-625.

41. Sarkar S, Kanungo DP and Mehrotra G (1995), "Landslide hazard zonation: a case study of Garhwal Himalaya, India", Mountain research and development 15: 301-309.

42. Shahabi H, Hashim M (2015) Landslide susceptibility mapping using GIS-based statistical models and Remote sensing data in tropical environment. Scientific reports 5: 9899. https://doi.org/10.1038/srep09899.

43. Sharma VK, Kumar H, Kumar P (2005) Macro-seismic investigation of Chamba earthquake of 14th April, 2005, Himachal Pradesh. Geol. Surv. India, Unpublished Report, FS 2004-2005.

44. Singh K and Kumar V (2018), "Hazard assessment of landslide disaster using information value method and analytical hierarchy process in highly tectonic Chamba region in bosom of Himalaya", Journal of mountain Science 15(4): 808-823. https://doi.org/10.1007/s11629-017-4634-2.

45. Singh K and Thakur VC (1990), "Strain analysis of the Chamba Syncline using deformed quartz pebbles in Chamba Syncline using deformed quartz pebbles in Chamba region of Northwestern Himalaya", Journal geological society of India 33: 140-149.

46. Singh KC and Sharma R (1997), “Magnesite along the Chamba thrust, Himachal Himalaya: Structural control and Depositional environment using fluid inclusions", Journal geological society of India 29-289-296.

47. Singh KC and Thakur VC (1986), "Crenulation cleavage in slate of the Chamba syncline: associated microstructures and origin”, Journal geological society of India 28:311-314.

48. Sujatha ER, Rajamanickam GV, Kumaravel P (2012) Landslide susceptibility analysis using probablistic certainty factor approach: a case study on Tevankarai stream watershed, India. Journal of earth system science 121(5): 1337-1350. https://doi.org/10.1007/s12040-012-0230-6.

49. Tandon SK and Thakur VC (1976), "stratigraphy and sedimentation of the majir formation, Chamba ditrict Himachal Pradesh", Bull. Ind. Geol. Association 9:94-104.

50. Thanh LN, De Smedt F (2012) Application of an analytical hierarchical process approach for landslide susceptibility mapping in a Luoi district, ThuaThien Hue Province, Vietnam. Environmental Earth Sciences 66(7): 1739-1752. https://doi.org/10.1007/s12665-011-1397-x.

51. Van Westen CJ, Rengers N and Soeters R (2003), "Use of geomorphological information in indirect landslide susceptibility assessment", Natural hazards 30(3): 399-419. https://doi.org/10.1023/B:NHAZ.000000 7097.42735.9e.

52. VanWesten CJ (1993) Application of geographic information systems to landslide hazard zonation.ITC Publication, vol. 15.International Institute for Aerospace and Earth Resources Survey, Enschede. p 245.

53. Vargas LG (1990), "An overview of the analytic hierarchy process and its applications", European journal of operational research1(48): 2-8.

54. Varnes DJ (1984), "Landslide Hazard Zonation: A Review of Principles and Practice", United Nations educational, scientific and cultural organization. $\mathrm{p} 63$.

55. Wadia DN (1931), "The syntaxes of the north-west Himalaya-its rocks, tectonics, and orogeny", Records of the geological survey of India 65: 189-220.

56. Yalcin A (2008), "GIS-based landslide susceptibility mapping using analytical hierarchy process and bivariate statistics in Ardesen (Turkey): comparisons of results and confirmations", Catena 72: 1-12. https://doi.org/10.1016/j.catena.2007.01.003.

57. Yan TZ (1988)' "Recent advances of quantitative prognoses of landslide in China", In: Proceedings of the fifth international symposium on landslides, Lausanne, Switzerland 2: 1263-1268. 
653 58. Yin KL and Yan TZ (1988), "Statistical prediction model for slope instability of metamorphosed rocks", In: 654 Bonnard C (ed.) Proc., fifth international symposium in landslides, Lausanne, A. A. Balkema, Rotterdam 2: $655 \quad 1269-1272$. 


\section{Figures}

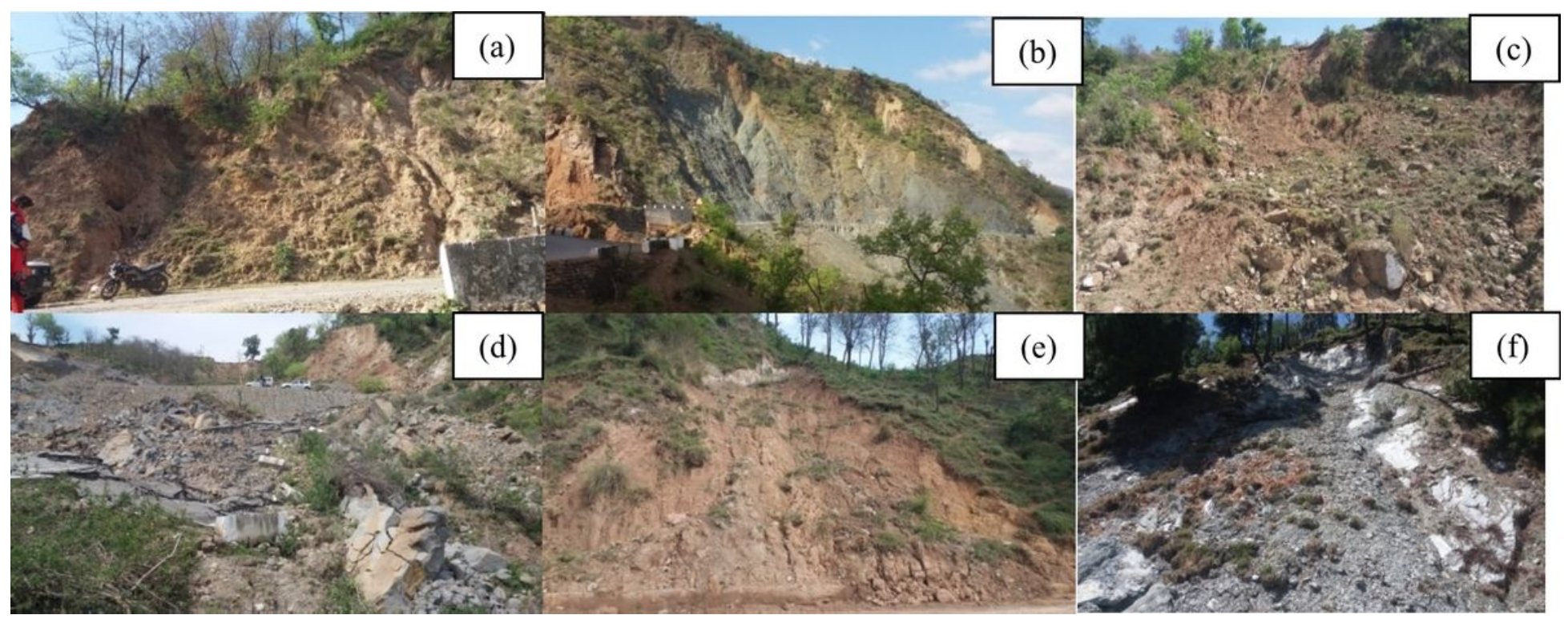

\section{Figure 1}

Photographs of critical slopes taken during March 2019 field visit along SH28 and NH -154A (a) Earth debris failure 500m from Lahru at SH28 (b) Transitional and Rock debris landslide near Chowari at SH28, (c) Debris flow landslide neat Jot at SH28 (d) Rock fall and Earth flow landslide 250m before Ghatasani bridge at NH145-A (e) Earth Debris flow landslide near Banikhet at NH-154A (f) Rock fall landslide near Chamba at NH154A. 

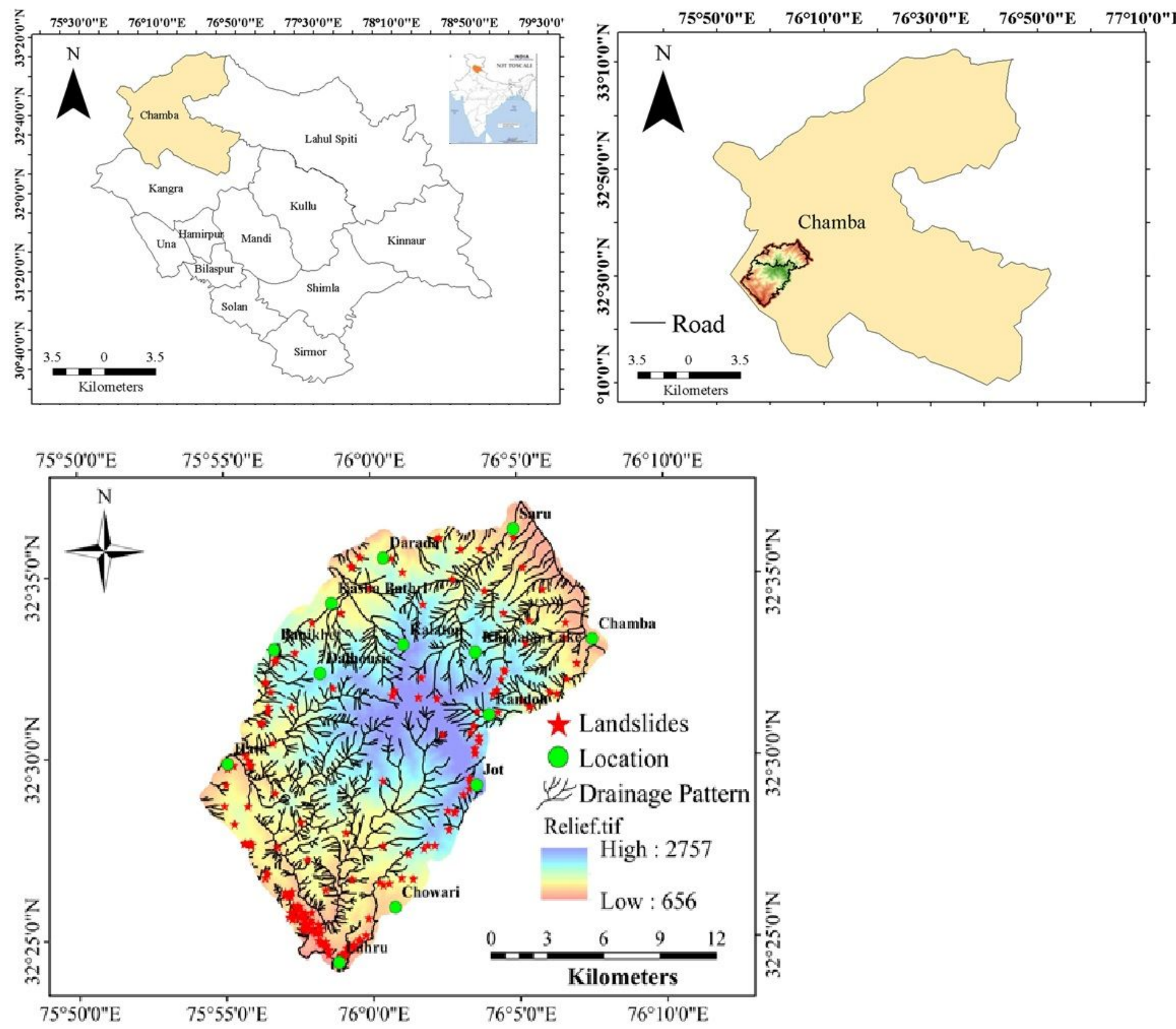

Figure 2

Study area Lahru to Chamba, Chamba District, and Himachal Pradesh, India 


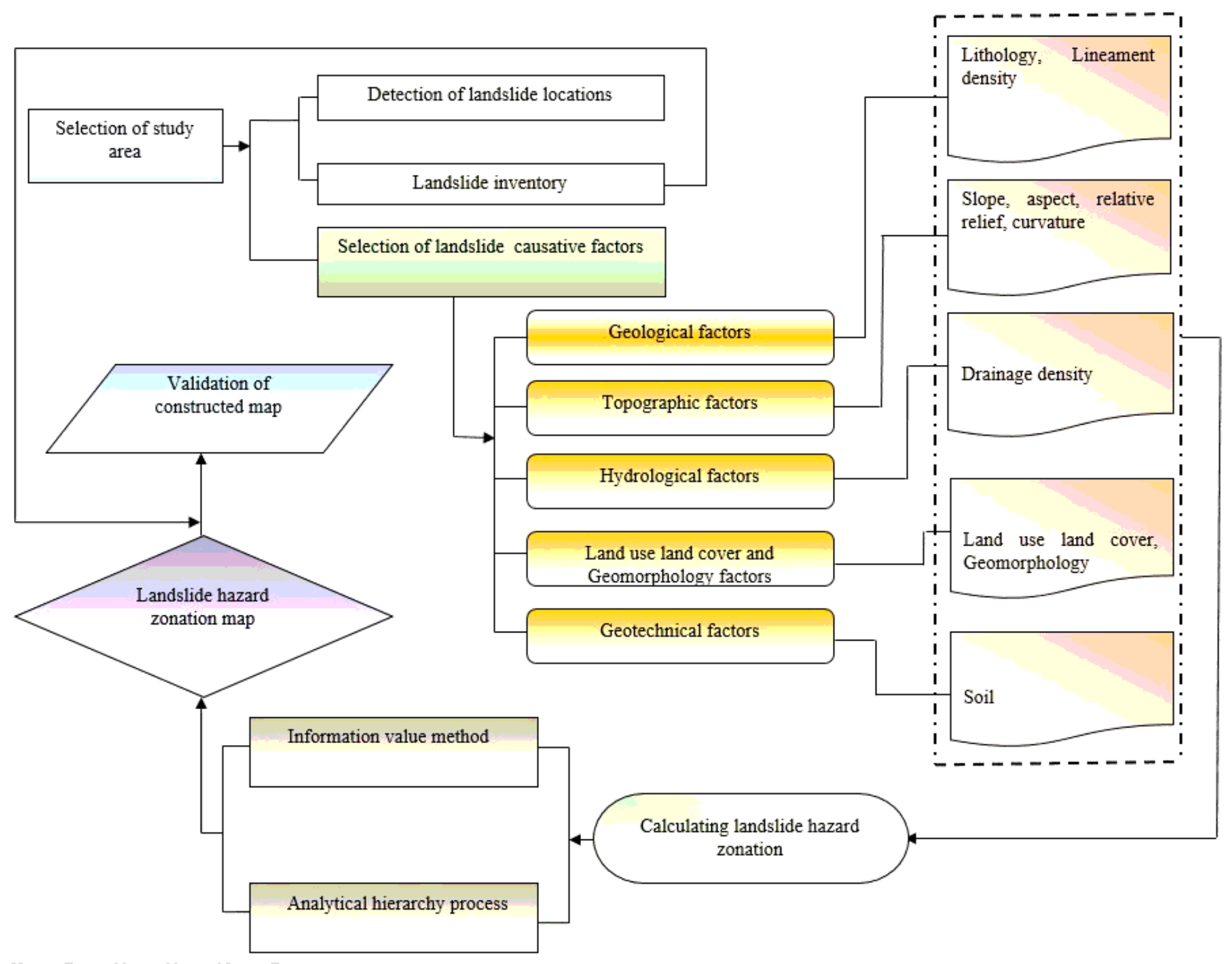

Figure 3

(Manuscript Figure 3.1) Flow chart for landslide hazard zonation mapping 

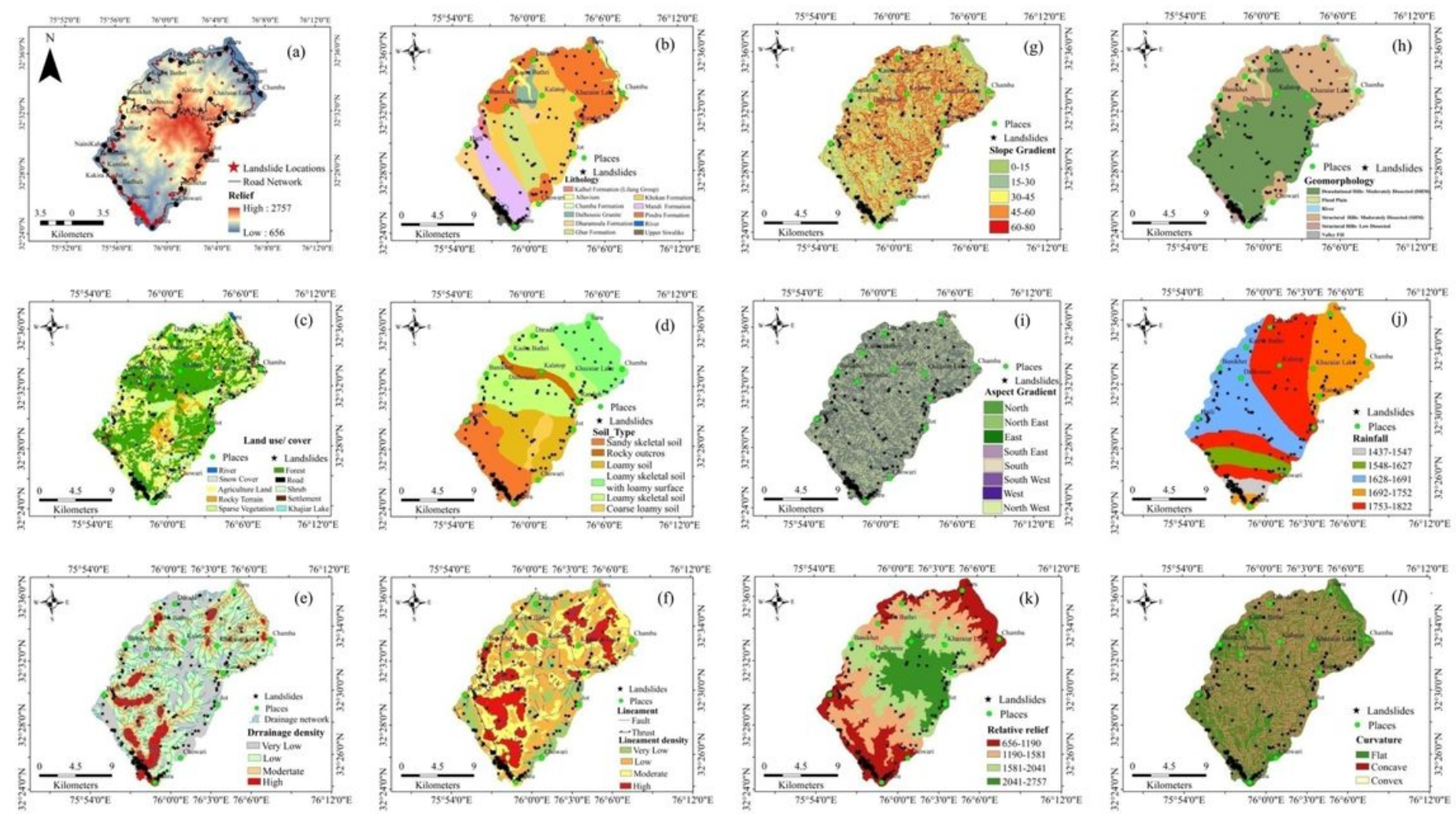

Figure 4

(Manuscript Figure 3.2-Figure 4) Thematic data layers (a) Landslide inventory map, (b) Lithology map, (c) Land use and cover map (d) Drainage density (e) Lineament Density map (f) Lineament density map. (g) Slope gradient map, (h) Geomorphology map, (i) Aspect map (j) Rainfall map (k) Relative relief map (l) Curvature map. 

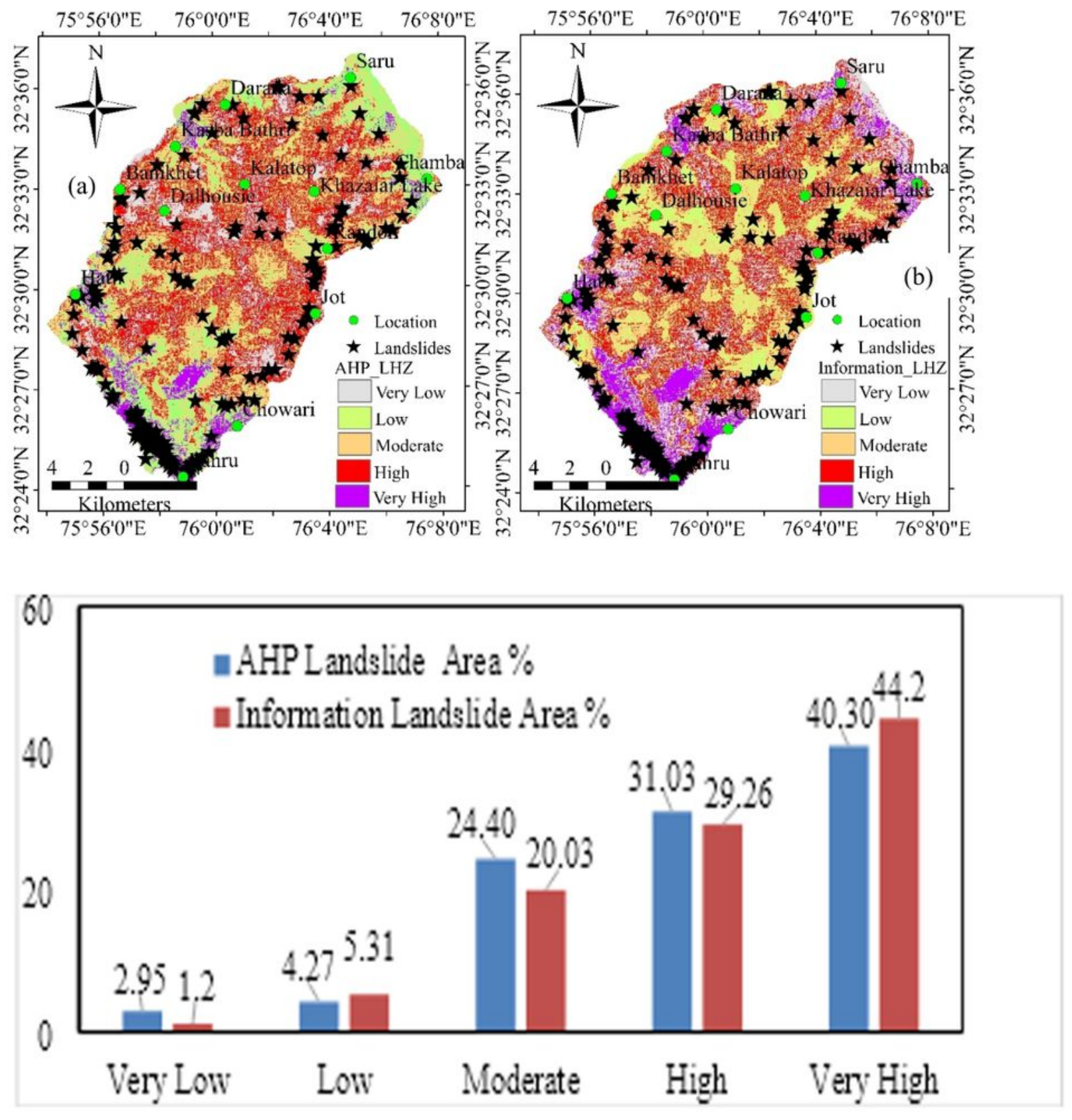

\section{Figure 5}

Landslide hazard zonation maps using AHP and Information value methods: (a) Analytical hierarchy process (AHP) hazard map (b) Information value (Inf.V) hazard map. (c) Landslide area percentage graph in each landslide hazard zone 


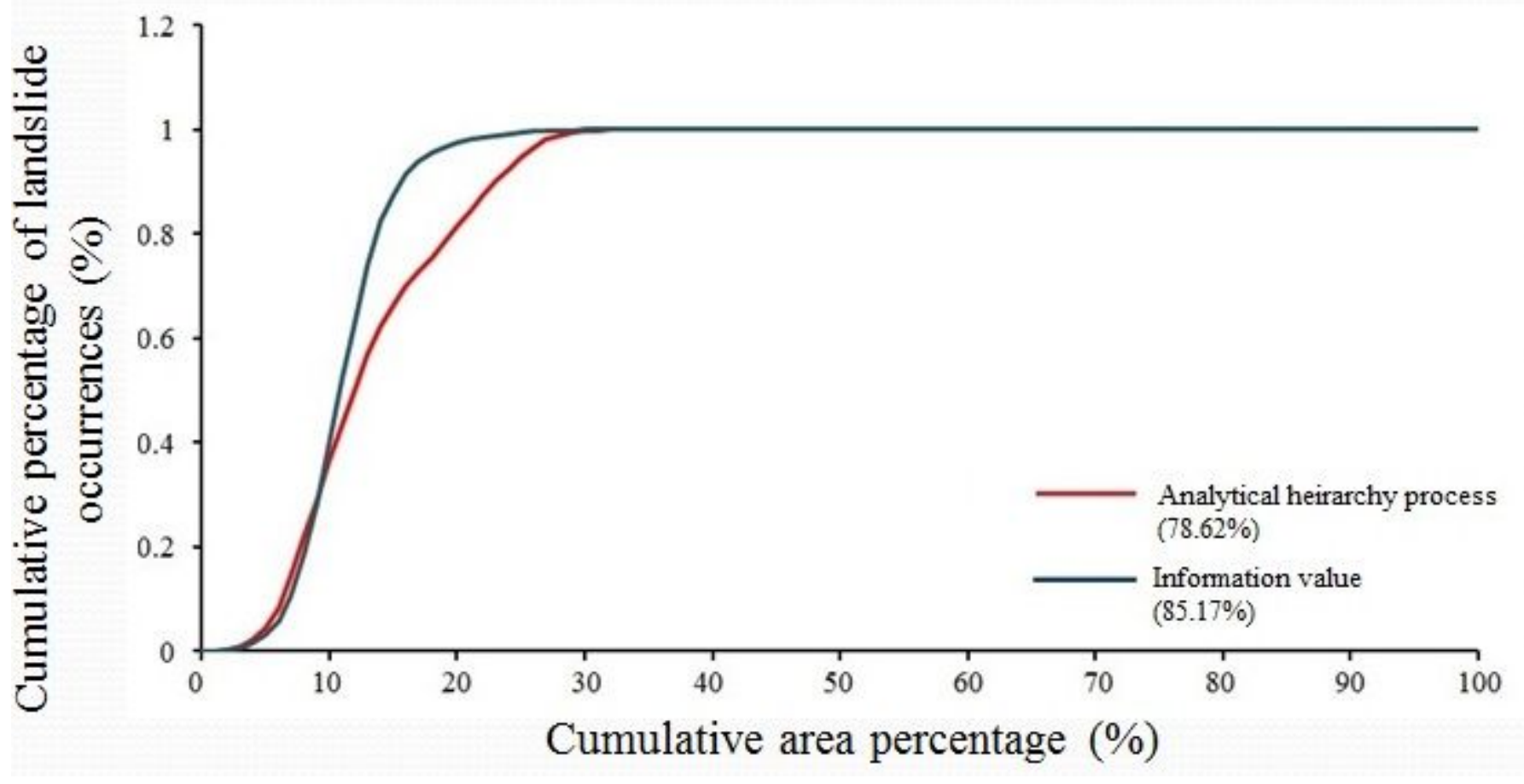

Figure 6

Successive rate curve method for validation of both AHP and Inf.V methods 